OPEN ACCESS

Edited by:

Myung-Shik Lee,

Yonsei University Health System,

South Korea

Reviewed by:

Hun Sik Kim,

University of Ulsan, South Korea

Helen Thomas,

St. Vincents Institute of Medical

Research, Australia

*Correspondence:

Louise Magnusson

louise.magnusson@liu.se

tThese authors have contributed equally to this work

Specialty section:

This article was submitted to Autoimmune and Autoinflammatory Disorders,

a section of the journal

Frontiers in Immunology

Received: 17 December 2019

Accepted: 05 February 2020

Published: 21 February 2020

Citation:

Magnusson L, Barcenilla H, Pihl M,

Bensing S, Espes D, Carlsson P-O and Casas $R$ (2020) Mass Cytometry Studies of Patients With Autoimmune

Endocrine Diseases Reveal Distinct

Disease-Specific Alterations in Immune Cell Subsets.

Front. Immunol. 11:288.

doi: 10.3389/fimmu.2020.00288

\section{Mass Cytometry Studies of Patients With Autoimmune Endocrine Diseases Reveal Distinct Disease-Specific Alterations in Immune Cell Subsets}

\author{
Louise Magnusson ${ }^{1,2 *}$, Hugo Barcenilla ${ }^{2}$, Mikael Pihl ${ }^{3}$, Sophie Bensing ${ }^{4}$, Daniel Espes ${ }^{1,5}$, \\ Per-Ola Carlsson ${ }^{1,5+}$ and Rosaura Casas $^{2 \dagger}$ \\ 'Department of Medical Sciences, Uppsala University, Uppsala, Sweden, ${ }^{2}$ Division of Children and Women Health, \\ Department of Biomedical and Clinical Sciences, Linköping University, Linköping, Sweden, ${ }^{3}$ Core Facility Flow Cytometry \\ Unit, Faculty of Medicine, Linköping University, Linköping, Sweden, ${ }^{4}$ Department of Molecular Medicine and Surgery, \\ Karolinska Institutet, Stockholm, Sweden, ${ }^{5}$ Department of Medical Cell Biology, Uppsala University, Uppsala, Sweden
}

Although there is evidence that autoimmune diseases share similar immunogenetic mechanisms, studies comparing peripheral $\mathrm{CD} 45^{+}$cells from patients with autoimmune endocrine diseases in parallel are limited. In this study, we applied high-dimensional single-cell mass cytometry to phenotypically characterize PBMC from patients with new-onset (N-T1D) and long-standing type 1 diabetes, Hashimoto's thyroiditis (HT), Graves' disease and autoimmune Addison's disease (AD), as well as healthy controls. The frequency of $\mathrm{CD} 2 \mathrm{O}^{\mathrm{lo}} \mathrm{CD} 27^{\mathrm{hi}} \mathrm{CD} 38^{\text {hi }} \mathrm{HLA}$-DR ${ }^{\text {int }}$ plasmablasts, $\mathrm{CD} 86^{+} \mathrm{CD} 14^{\mathrm{lo}} \mathrm{CD} 16^{+}$ non-classical monocytes and two subsets of CD56 dim HLA-DR ${ }^{+} \mathrm{IFN}-\gamma^{+} \mathrm{NK}$ cells were increased in patients with HT. Subsets of CD56 ${ }^{\text {dim }^{2}} \mathrm{CD} 69^{+} \mathrm{HLA}-\mathrm{DR}{ }^{-}$NK cells and CD8 ${ }^{+}$ TEMRA cells, both expressing IFN- $\gamma$, were expanded and reduced, respectively, in the N-T1D group. In addition, patients with AD were characterized by an increased percentage of central memory CD8 ${ }^{+}$T cells that expressed CCR4, GATA3, and IL-2. We demonstrate that patients with N-T1D, HT, and AD had altered frequencies of distinct subsets within antigen-presenting and cytotoxic cell lineages. Previously unreported alterations of specific cell subsets were identified in samples from patients with HT and AD. Our study might contribute to a better understanding of shared and diverging immunological features between autoimmune endocrine diseases.

\footnotetext{
Keywords: mass cytometry (CyTOF), type 1 diabetes, Hashimoto's thyroiditis, Graves' disease, Addison's disease, antigen-presenting cells, NK cells, $\mathrm{T}$ cells
}

\section{INTRODUCTION}

Despite that targets and symptoms vary between autoimmune diseases, several features underlying autoimmunity are considered to be shared. This idea is not novel as "mosaic of autoimmunity" and "autoimmune tautology" are established concepts $(1,2)$. These concepts declare that genetic and epigenetic factors predispose individuals to fail central and peripheral tolerance mechanisms. 
An autoimmune response can later be triggered by inauspicious hormonal background and environmental factors, leading to overt disease. This model pertains all autoimmune diseases, although specific genetic, hormonal, immunological, and environmental factors and their interactions determine the final disease.

As a large proportion of patients with type 1 diabetes (T1D), Hashimoto's thyroiditis (HT), Graves' disease (GD), and autoimmune Addison's disease (AD) develop polyautoimmunity or Autoimmune Polyendocrine Syndrome (2-5), it can be expected that patients with these diseases have similar immunological deviations. Autoantibodies produced by $\mathrm{B}$ cells are the most evident immunological feature in patients with T1D, HT, GD and AD, which can directly cause symptoms and modulate the function of other immune cells (6-8). Evidence suggests that monocytes (Mo) and antigenpresenting cells are also involved in the inflammatory process by the secretion of cytokines that induce differentiation of pro-inflammatory effector $\mathrm{T}$ cells $(6,9)$. Indeed, a typical feature for T1D, HT, GD, and $\mathrm{AD}$ is the presence of $\mathrm{CD}^{+}$ and $\mathrm{CD}^{+} \mathrm{T}$ cells that lyse target cells and secrete IFN- $\gamma$ and TNF- $\alpha$ upon autoantigen stimulation $(6,10-13)$. Studies addressing $\mathrm{T}$ cells in autoimmune endocrine diseases have nevertheless described a more complex process, as increased Th2-/Th17-biased immune responses (13-15) and a defective immunomodulation by Tregs $(16,17)$ have been reported. An issue with the abovementioned studies is that no or few simultaneous comparisons between diseases have been made, as patients with only one autoimmune condition have been mostly recruited. Another issue is that immune deviations associated with autoimmune endocrine diseases have been examined within a limited number of major cell lineages due to methodological limitations.

Mass cytometry is a high-dimensional single-cell technology that enables simultaneous characterization of the immune system, which has yielded novel information about T1D (1820), systemic lupus erythematous (21) and rheumatoid arthritis (22). A limited number of studies have used this approach to compare different diseases in parallel $(23,24)$, but none have focused on immunological features in patients with autoimmune endocrine diseases. In our study, we used mass cytometry to perform a deep characterization and simultaneous comparison of PBMC from patients with T1D, HT, GD, and $\mathrm{AD}$. By applying hierarchical dimensionality reduction and clustering analyses, we identified distinct subsets within $\mathrm{B}$ cells, Mo, NK cells and memory $\mathrm{CD}^{+} \mathrm{T}$ cells that were altered in patients with new-onset T1D (N-T1D), HT, and $\mathrm{AD}$.

\section{RESULTS}

We used a mass cytometry panel with 32 lanthanide-labeled antibodies, including markers for lineage, activation/function, differentiation, cytokines, chemokine receptors and transcription factors, to phenotypically characterize PBMC. Samples from patients with N-T1D, long-standing T1D (L-T1D), $\mathrm{HT}, \mathrm{GD}$, and $\mathrm{AD}$, as well as healthy controls (HC), were examined in this study. The hierarchical stochastic neighbor embedding (HSNE) dimensionality reduction analysis and unsupervised Gaussian mean-shift (GMS) clustering were applied to reveal the composition of single live $\mathrm{CD} 45^{+}$cells (Supplementary Figure 1A).

Based on the expression of lineage markers, eight major cell lineages were identified: $\mathrm{CD} 19^{+} \mathrm{B}$ cells, $\mathrm{CD} 14^{+} \mathrm{Mo}$, $\mathrm{lin}^{-} \mathrm{CD} 56^{+}$ $\mathrm{NK}$ cells and innate lymphoid cells (ILC), $\mathrm{CD}^{+}{ }^{+} \mathrm{CD} 8^{+}$and $\mathrm{CD}^{+}{ }^{+} \mathrm{CD} 4^{+} \mathrm{T}$ cells, $\mathrm{CD} 4{ }^{+} \mathrm{CD} 25^{\text {hi }} \mathrm{CD} 127^{\text {lo }} \mathrm{FOXP} 3^{+}$Tregs, lin $^{-} \mathrm{CD} 11 \mathrm{c}^{+} \mathrm{CD} 123^{-}$myeloid dendritic cells $(\mathrm{mDC})$ and $\operatorname{lin}^{-} \mathrm{CD} 11 \mathrm{c}^{-} \mathrm{CD} 123^{+}$plasmacytoid dendritic cells (pDC) (Figure 1A). Quantification of their relative frequencies in each sample corroborated that $\mathrm{CD}^{+} \mathrm{T}$ cells were the most abundant cell type within $\mathrm{CD} 45^{+}$cells, whereas proportions of $\mathrm{CD} 19^{+} \mathrm{B}$ cells, $\mathrm{CD} 14^{+}$Mo and $\operatorname{lin}^{-} \mathrm{CD} 56^{+} \mathrm{NK}$ cells/ILC varied between subjects (Figure 1B). Despite the large individual variability, there were no differences in the frequency of major cell lineages between the groups. Every cell lineage was then selected and explored in detail by HSNE to identify clusters, as exemplified by $\mathrm{CD}^{+} \mathrm{T}$ cells (Figure 1C). Our results revealed a total of 125 phenotypically distinct subsets, illustrating a high degree of heterogeneity within PBMC (Supplementary Figure 1B). HSNE maps generated by the analyses of $\mathrm{CD}^{+} 5^{+}$cells were similar in patients and $\mathrm{HC}$ (Supplementary Figure 2). However, the statistical analysis of each cluster revealed alterations within some subsets of $\mathrm{B}$ cells, Mo, NK cells, and memory $\mathrm{CD} 8^{+} \mathrm{T}$ cells in three groups of patients.

\section{CD19+ B Cell and CD14+ Monocyte Subsets Were Specifically Altered in Patients With HT}

Clustering of the $\mathrm{CD}_{1} 9^{+} \mathrm{B}$ cell lineage defined 21 phenotypically distinct clusters, where the majority comprised $\mathrm{CD} 27^{-} \mathrm{B}$ cells (Figures 2A,B). Although $\mathrm{CD} 20^{\mathrm{lo}} \mathrm{CD} 27^{\mathrm{hi}} \mathrm{CD} 38^{\mathrm{hi}} \mathrm{HLA}-\mathrm{DR} \mathrm{R}^{\mathrm{int}}$ plasmablasts (B \#16) only constituted $0.1-2 \%$ of $\mathrm{CD} 19^{+} \mathrm{B}$ cells, this cell subset was more frequent in patients with HT than in HC $(p=0.006)$ and patients with N-T1D $(p=0.04)$, GD $(p=0.04)$, and $\operatorname{AD}(p=0.02$, Figure $2 \mathrm{C})$. We identified

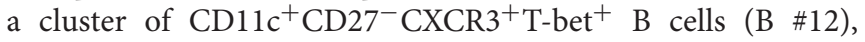
which have been previously associated with autoimmune diseases $(25,26)$. This cell subset was more frequent in patients with HT although it only reached a statistical difference with the N-T1D group (Supplementary Figure 3). The level of cytokine expression within the whole B cell lineage was low, which precluded us to define cytokine expression within specific clusters.

The hierarchical analysis of the $\mathrm{CD} 14^{+}$Mo lineage identified eight clusters (Figures 3A,B). Patients with HT had a higher frequency of $\mathrm{CD} 86^{+} \mathrm{CD} 14^{\mathrm{lo}} \mathrm{CD} 16^{+}$non-classical Mo (\#6) than HC $(p=0.0005)$ and patients with N-T1D $(p=0.0005)$, LT1D $(p=0.01)$ and $\mathrm{AD}(p=0.003$, Figure 3C). In spite of evident disease-associated signatures in the lineage-context 


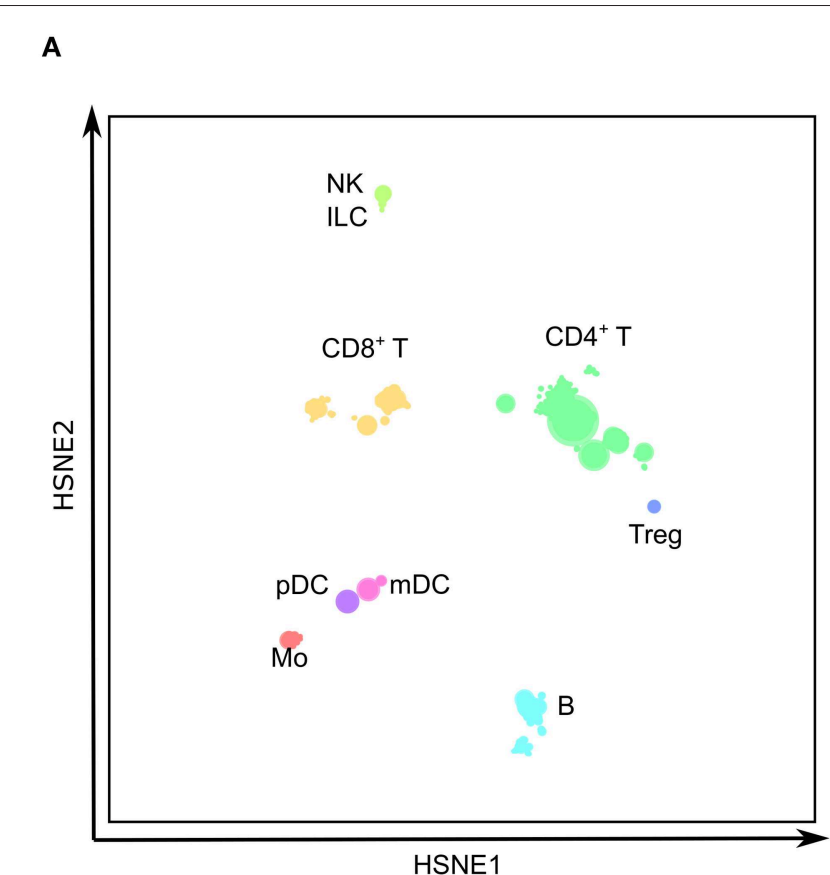

HSNE1

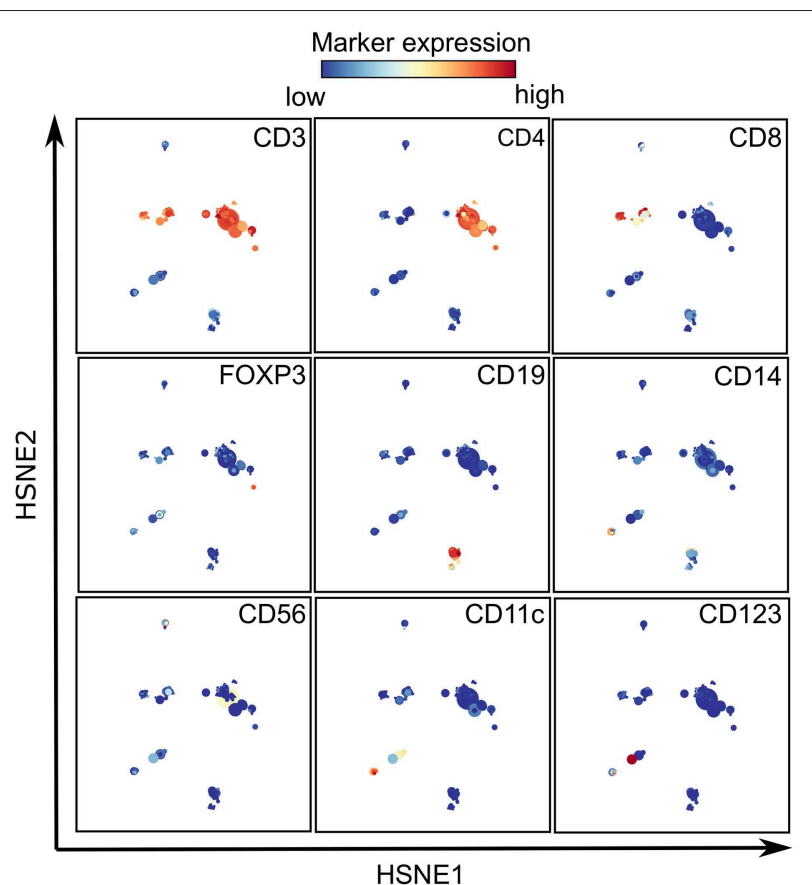

HSNE1

\section{B}

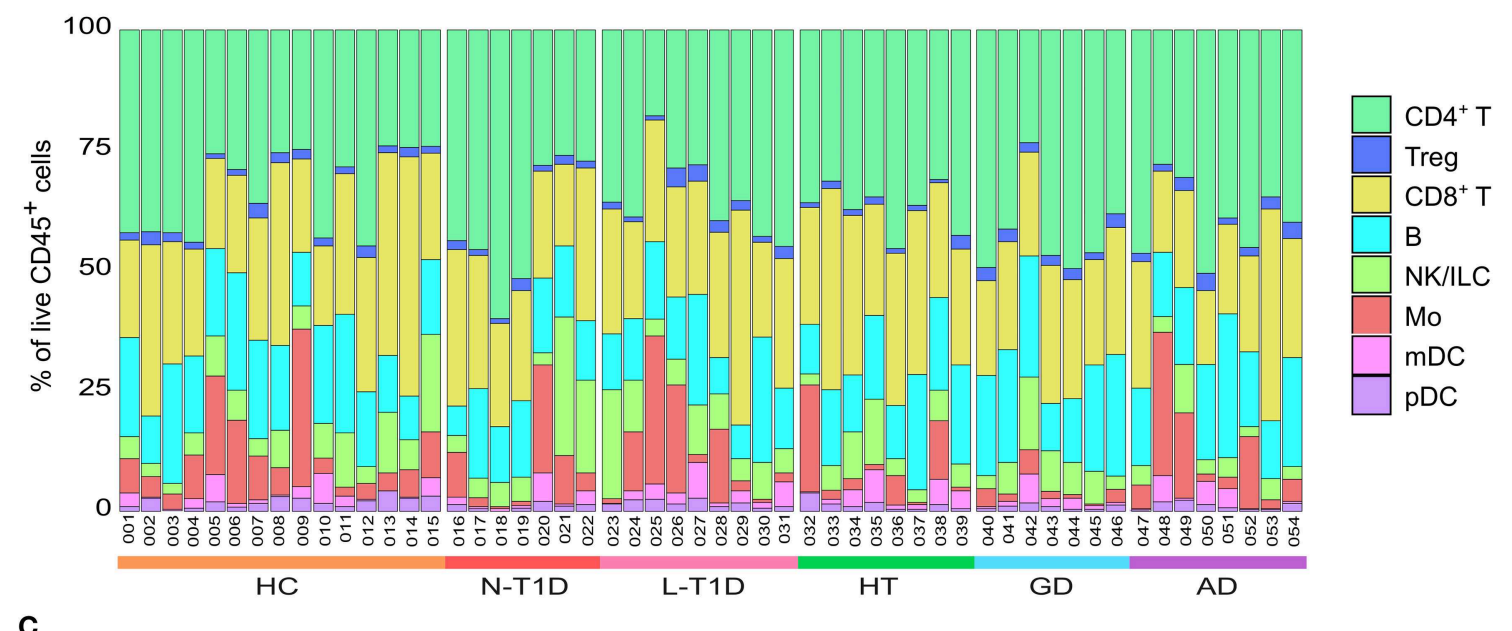

C

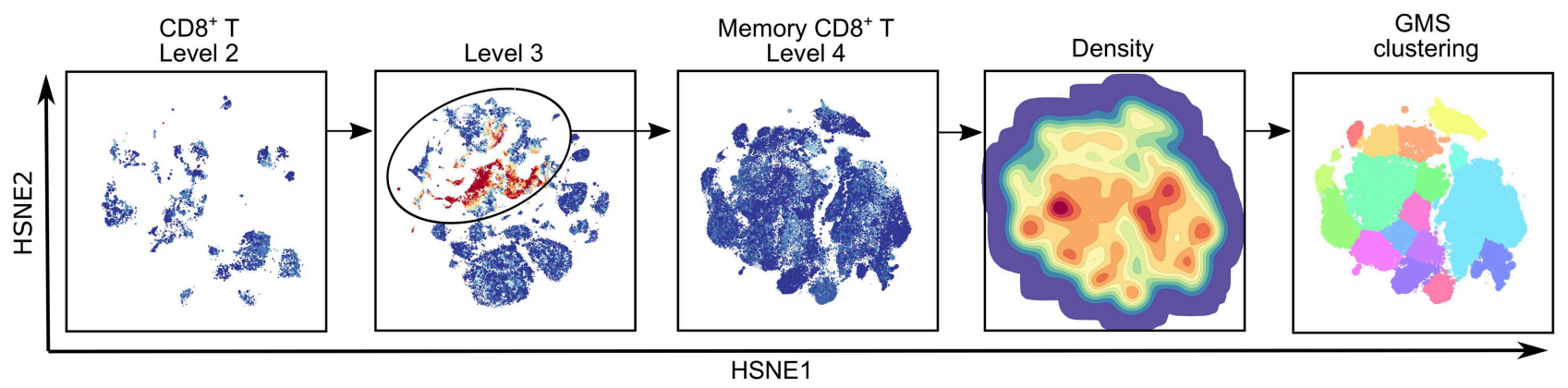

FIGURE 1 | Delineation of major cell lineages within PBMC. (A) A HSNE-embedding at the overview level showing a collective analysis of PBMC from healthy controls ( $\mathrm{HC}, n=15)$ and patients with new-onset (N-T1D, $n=7$ ) and long-standing (L-T1D, $n=9$ ) type 1 diabetes, Hashimoto's thyroiditis $(H \mathrm{HT}, n=8), \mathrm{Graves}$ ' disease (GD, $n=7)$ and autoimmune Addison's disease (AD, $n=8$ ). Eight major cell lineages (left) were defined based on the ArcSinh5-transformed expression of conventional lineage markers (right). (B) Proportions (\%) of the different lineages in live CD45 cells. Numbers and colors below the bar graph represent individuals (001-054) and groups, respectively. (C) Example of hierarchal data exploration applied on all cell lineages. The $\mathrm{CD} 8^{+} \mathrm{T}$ cell lineage from the overview level was selected and 
FIGURE 1 l embedded at more detailed levels. Memory CD8 ${ }^{+}$T cells (black circle) were selected at level 3 based on CD45RO expression. At level 4, unsupervised Gaussian mean-shift (GMS) clustering used the local probability density of HSNE-embedded cells (density map) to identify phenotypically distinct clusters (color partitions). ILC, innate lymphoid cell; HSNE, hierarchical stochastic neighbor embedding.

A

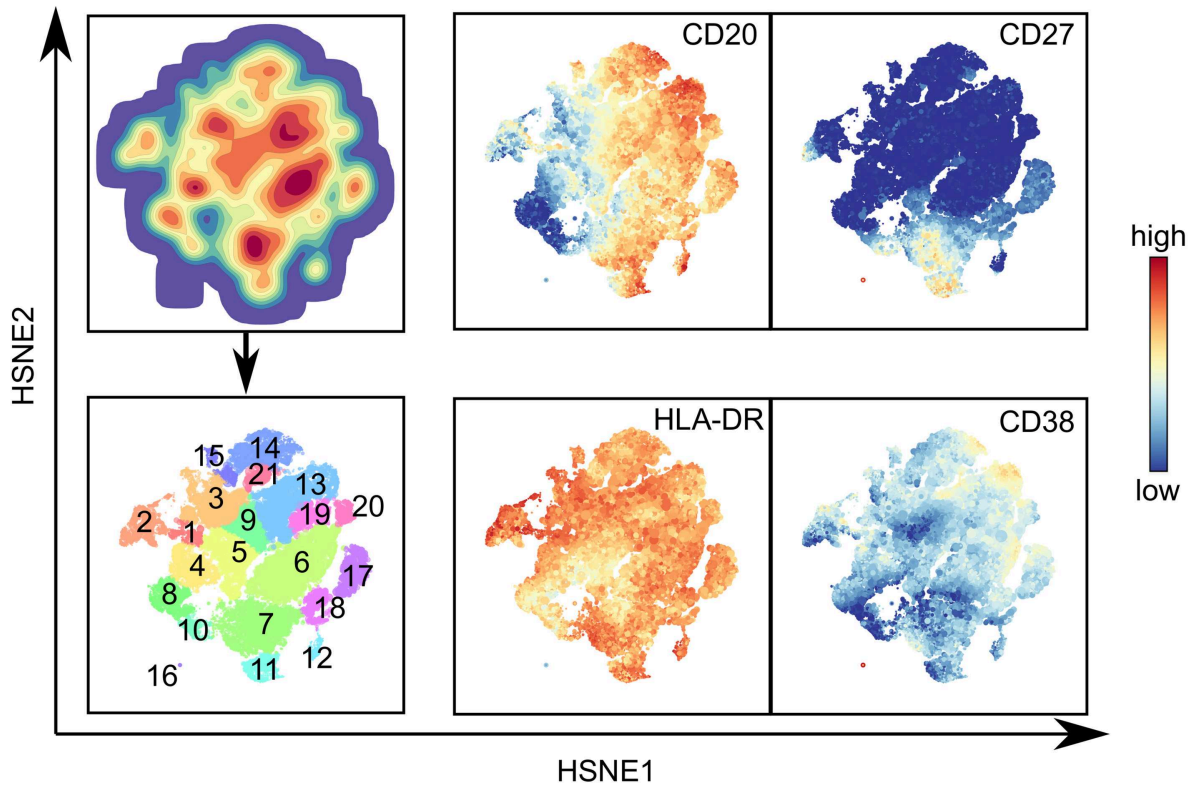

B

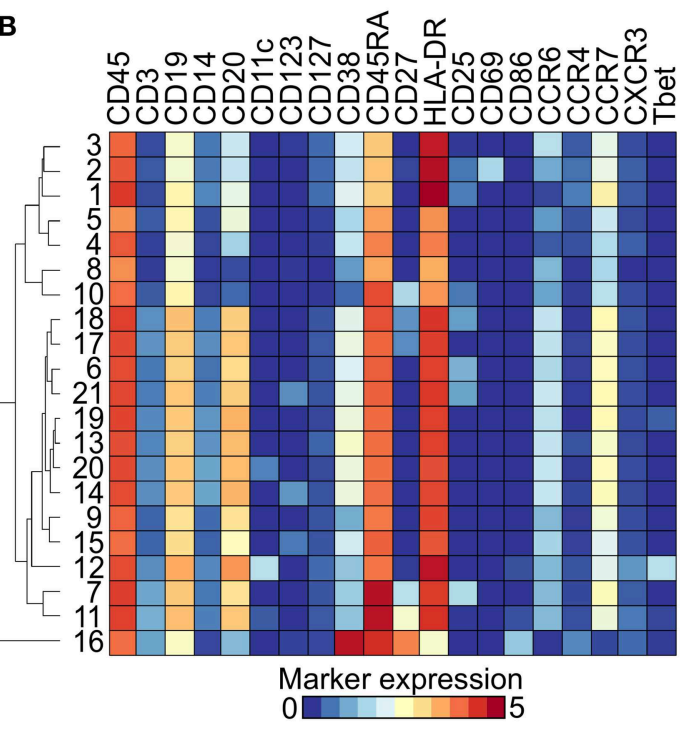

C

Plasmablast (\#16)

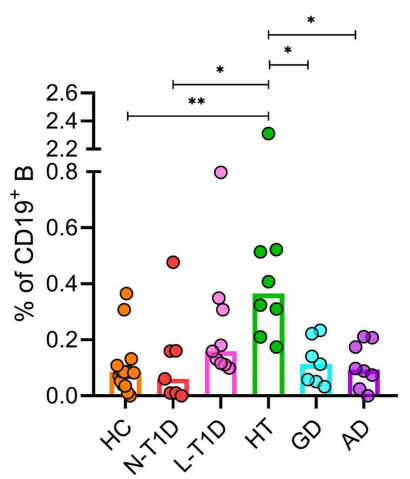

FIGURE 2 | Expansion of plasmablasts in patients with Hashimoto's thyroiditis. (A) HSNE-embedding depicting the local probability density of CD19+ B cells (upper first left) and the subsets defined by Gaussian mean-shift clustering (lower first left). Relative expression of selected markers in embedded CD19+ B cells. (B) Heatmap showing ArcSinh5-transformed median expression of relevant markers within the clusters identified in (A). The dendrogram depicts hierarchical clustering of subsets. (C) Frequency of plasmablasts (\#16) in healthy controls (HC, $n=15)$ and patients with new-onset (N-T1D, $n=7)$ and long-standing (L-T1D, $n=9)$ type 1 diabetes, Hashimoto's thyroiditis (HT, $n=8)$, Graves' disease (GD, $n=7)$ and autoimmune Addison's disease (AD, $n=8)$. Dots represent individual samples and bars indicate median. One-way ANOVA with Tukey's test for multiple comparisons, ${ }^{*} p<0.05$ and ${ }^{* *} p<0.01$. HSNE, hierarchical stochastic neighbor embedding.

(Supplementary Figure 2), no other differences were observed between the groups. We were not able to detect cytokine expression in $\mathrm{CD} 14^{+}$Mo.
HSNE analysis of the mDC and pDC lineages identified six and four clusters, respectively (Supplementary Figures 4E,F). Neither cluster differed between the groups. 


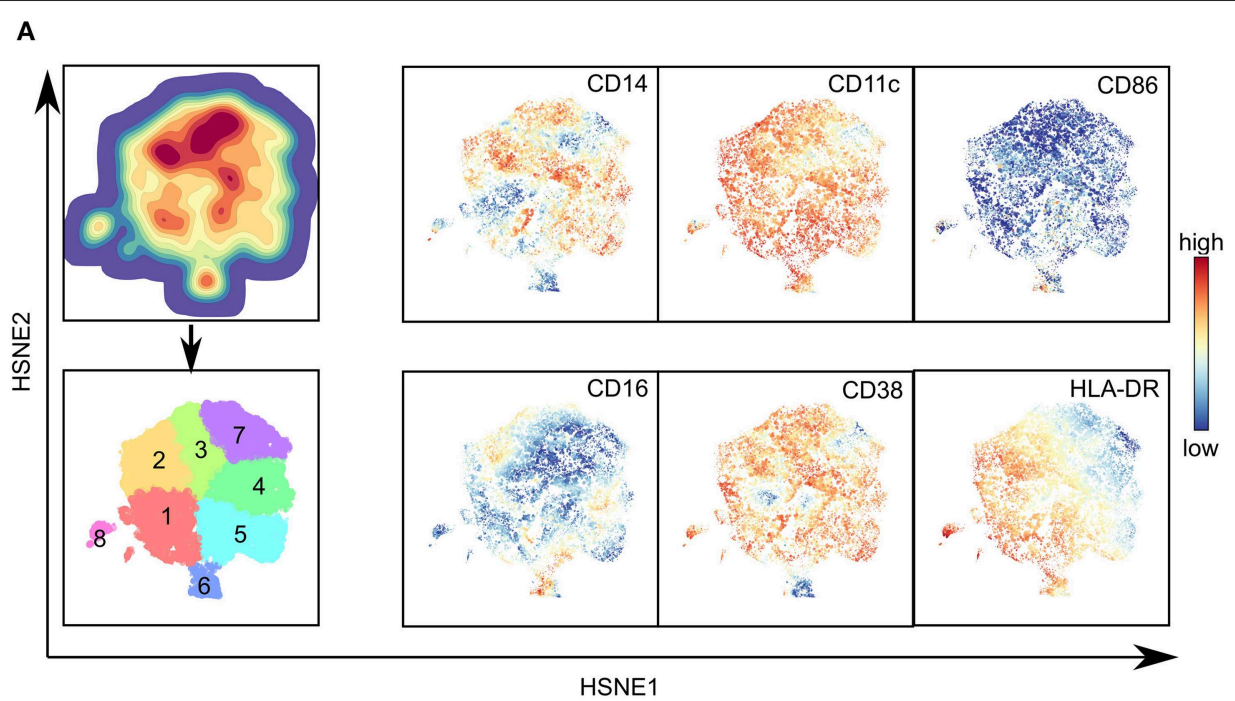

B

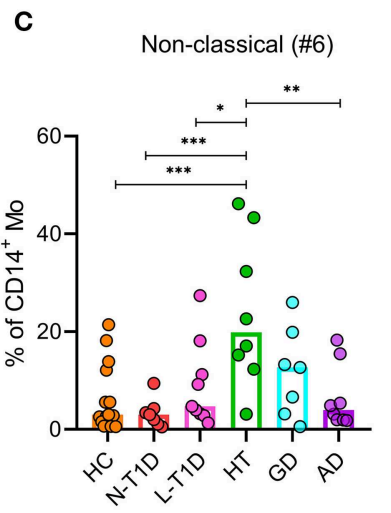

FIGURE 3 | Higher frequency of non-classical monocytes in patients with Hashimoto's thyroiditis. (A) HSNE-embedding depicting the local probability density of $\mathrm{CD}_{14} 4^{+} \mathrm{Mo}$ (upper first left) and subsets defined by Gaussian mean-shift clustering (lower first left). Relative expression of selected markers in embedded CD14 ${ }^{+}$Mo. (B) Heatmap showing ArcSinh5-transformed median expression of relevant markers within the clusters identified in (A). The dendrogram depicts hierarchical clustering of subsets. (C) Frequency of non-classical Mo (\#6) in healthy controls ( $\mathrm{HC}, n=15)$ and patients with new-onset (N-T1D, $n=7)$ and long-standing (L-T1D, $n=9)$ type 1 diabetes, Hashimoto's thyroiditis ( $\mathrm{HT}, n=8)$, Graves' disease (GD, $n=7$ ) and autoimmune Addison's disease (AD, $n=8)$. Dots represent individual samples and bars indicate median. One-way ANOVA with Tukey's test for multiple comparisons, ${ }^{*} p<0.05,{ }^{* *} p<0.01$, and ${ }^{\star \star *} p<0.001$. HSNE, hierarchical stochastic neighbor embedding; Mo, monocytes.

\section{Alterations in CD56 dim NK Cell Subsets Expressing IFN- $\gamma$ Were Characteristic for Patients With N-T1D and HT}

Clustering of lin $^{-} \mathrm{CD} 56^{+} \mathrm{NK}$ cells and ILC defined 14 subsets (Figure 4A). Thirteen of them expressed T-bet and IFN- $\gamma$, which could thus be classified as group 1 ILC (Figure 4B). A cluster of $\mathrm{CD}^{-} 6^{-} \mathrm{GATA}^{+}$ILC2 (NK \#8) also clustered within the NK cell lineage. Independent statistical analysis revealed that patients with $\mathrm{N}-\mathrm{T} 1 \mathrm{D}$ had a higher frequency of $\mathrm{CD}^{-} \mathrm{CD}^{-} 1 \mathrm{c}^{+} \mathrm{CD} 56^{\mathrm{dim}} \mathrm{CD} 69^{+} \mathrm{HLA}^{\mathrm{DLR}}{ }^{-} \mathrm{IFN}-\gamma^{+} \mathrm{NK}$ cells $(\mathrm{NK} \# 3)$ than $\mathrm{HC}(p=0.03)$ and patients with $\mathrm{HT}(p$ $=0.003)$ and GD $(p=0.03$, Figure 4C). Two subsets of CD56 ${ }^{\text {dim }}$ HLA-DR ${ }^{+}$NK cells were specifically abundant in patients with HT. The $\mathrm{CD}^{-} \mathrm{CD}^{-} 1 \mathrm{c}^{-}$cluster (NK \#10) was more frequent compared with HC $(p=0.004)$ and the L-T1D $(p=0.02)$ and GD groups $(p=0.02)$, whereas the frequency of $\mathrm{CD}^{+} \mathrm{CD}^{+} \mathrm{c}^{+}$cells $(\mathrm{NK} \# 11)$ was higher than in $\mathrm{HC}(p=$ $0.04)$ and the N-T1D $(p=0.003)$ and AD groups $(p=0.046)$. These two subsets expressed high levels of IFN- $\gamma$, which was comparable to the production by CD56 ${ }^{\text {hi }}$ NK cells (NK \#12) (Figure 4B).

\section{Distinct Memory Subsets and Altered Cytokine Expression in CD8 ${ }^{+} \mathrm{T}$ Cells Were Associated With Patients With N-T1D and AD}

Seventeen memory $\mathrm{CD}^{+} \mathrm{T}$ cell subsets were identified by clustering analysis (Figures 5 A,B). Patients with N-T1D had a lower frequency of $\mathrm{CD}_{4} 5 \mathrm{RA}^{+} \mathrm{CD}^{-} 7^{-} \mathrm{CCR}^{-}{ }^{-} \mathrm{CXCR}^{+} \mathrm{T}-$ bet ${ }^{+}$IFN- $\gamma^{+}$TEMRA cells $(\mathrm{CD} 8 \# 10)$ than HC $(p=0.04)$ and 


\section{A}

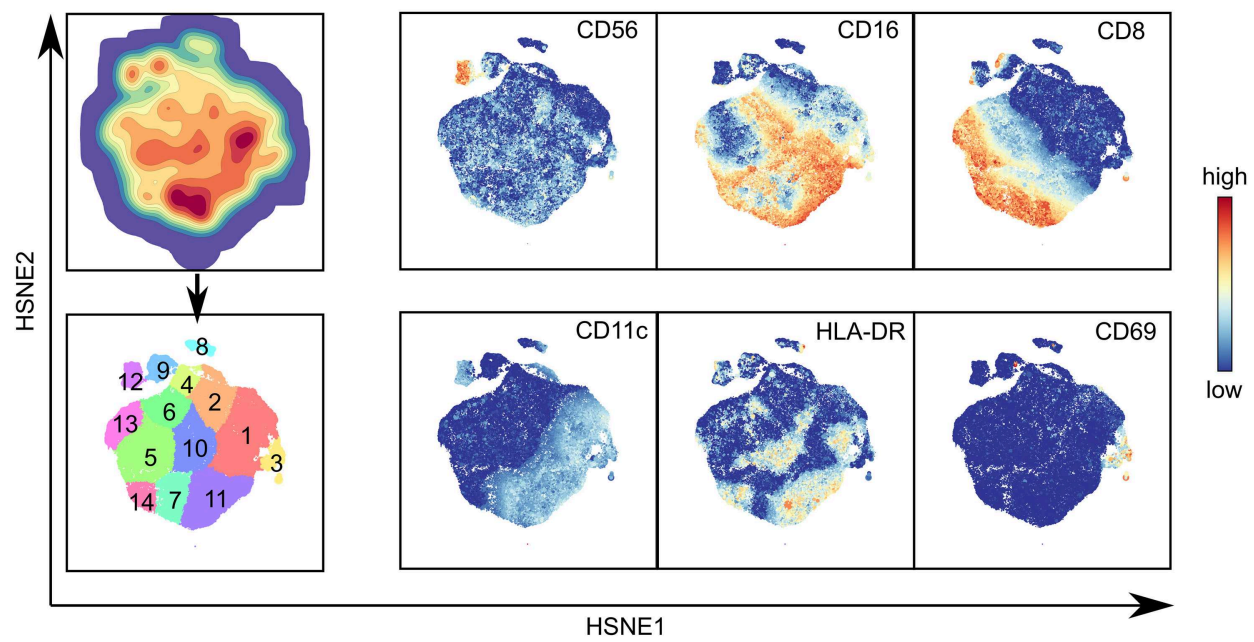

B

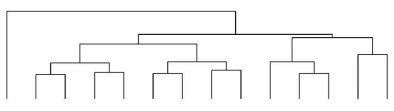

8131025711141346129

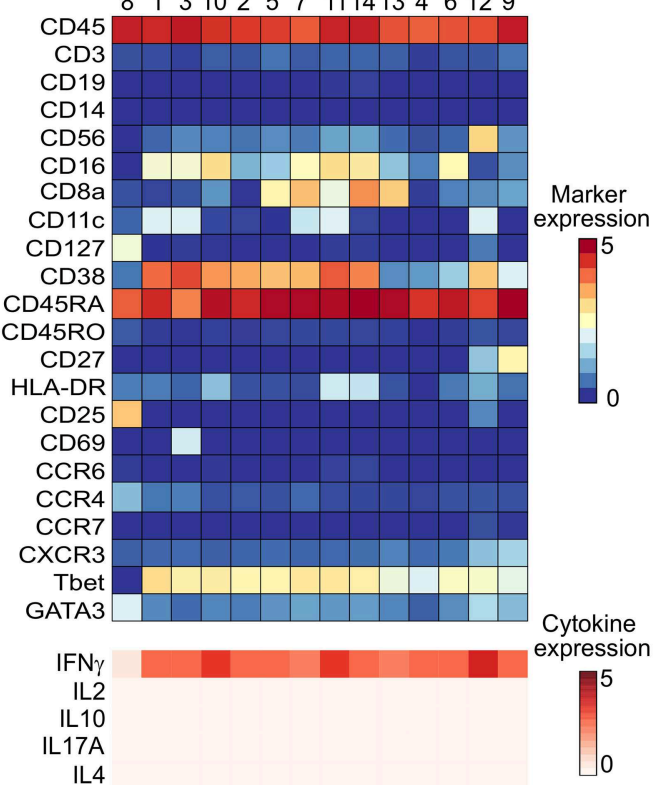

C $\quad \mathrm{CD}^{-} \mathrm{CD} 11 \mathrm{C}^{-} \mathrm{HLADR}^{+}(\# 10)$

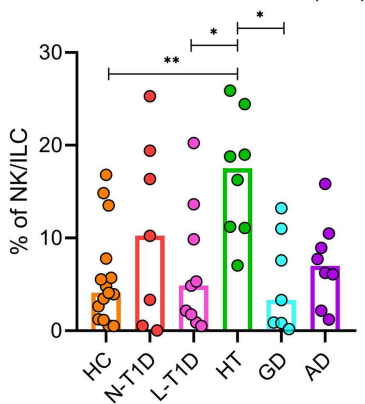

$\mathrm{CD}^{+} \mathrm{CD} 11 \mathrm{c}^{+} \mathrm{HLADR}^{+}(\# 11)$

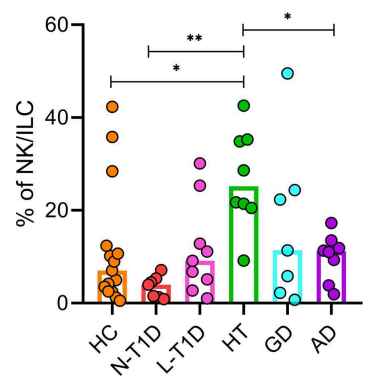

$\mathrm{CD}^{+} 9^{+}(\# 3)$

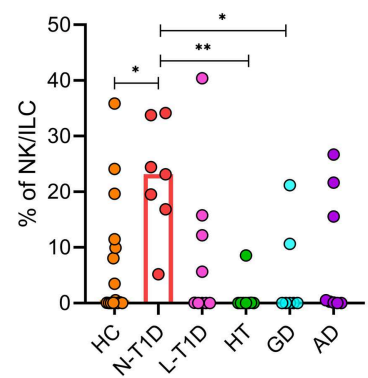

FIGURE 4 | Alterations in distinct CD56 dim NK cell clusters in patients with new-onset type 1 diabetes and Hashimoto's thyroiditis. (A) HSNE-embedding depicting the local probability density of CD56 ${ }^{+} \mathrm{NK}$ cells and ILC (upper first left) and the subsets defined by Gaussian mean-shift clustering (lower first left). Relative expression of selected markers in embedded CD56 $6^{+}$NK cells and ILC. (B) Heatmap showing ArcSinh5-transformed median expression of relevant markers (top) and differential median ArcSinh5-expression of cytokines after PMA/ionomycin stimulation (bottom) within the clusters identified in (A). The dendrogram depicts hierarchical clustering of subsets. (C) Frequencies of $\mathrm{CD}^{2} 9^{+}(\# 3), \mathrm{CD}^{-} \mathrm{CD} 11 \mathrm{c}^{-} \mathrm{HLA}^{-D R^{+}}(\# 10)$, and $\mathrm{CD} 8^{+} \mathrm{CD} 11 \mathrm{c}^{+} \mathrm{HLA}-\mathrm{DR}{ }^{+}(\# 11) \mathrm{NK}$ cells in healthy controls (HC, $\left.n=15\right)$ and patients with new-onset (N-T1D, $n=7$ ) and long-standing (L-T1D, $n=9$ ) type 1 diabetes, Hashimoto's thyroiditis (HT, $n=8)$, Graves' disease (GD, $n=7)$ and autoimmune Addison's disease (AD, $n=8$ ). Dots represent individual samples and bars indicate median. One-way ANOVA with Tukey's test for multiple comparisons, ${ }^{*} p<0.05$ and ${ }^{* *} p<0.01$. HSNE, hierarchical stochastic neighbor embedding; ILC, innate lymphoid cells.

the HT $(p=0.003)$ and GD groups $(p=0.01$, Figure 5C). A cluster of $\mathrm{CCR}^{+} \mathrm{GATA}^{+}$central memory cells $(\mathrm{CD} 8$ \#5) expressed low levels of IL-2, which was more frequent in patients with AD than in all other groups $(p<0.0001$ vs. HC and
HT, $p=0.0009$ vs. N-T1D, $p=0.0001$ vs. L-T1D, $p=0.004$ vs. GD). Although the expression of IL-2 was low in CD8 \#5, this subset accounted for most of the IL-2 expression within memory $\mathrm{CD} 8^{+} \mathrm{T}$ cells. The percentage of memory $\mathrm{CD} 8^{+} \mathrm{T}$ cells 


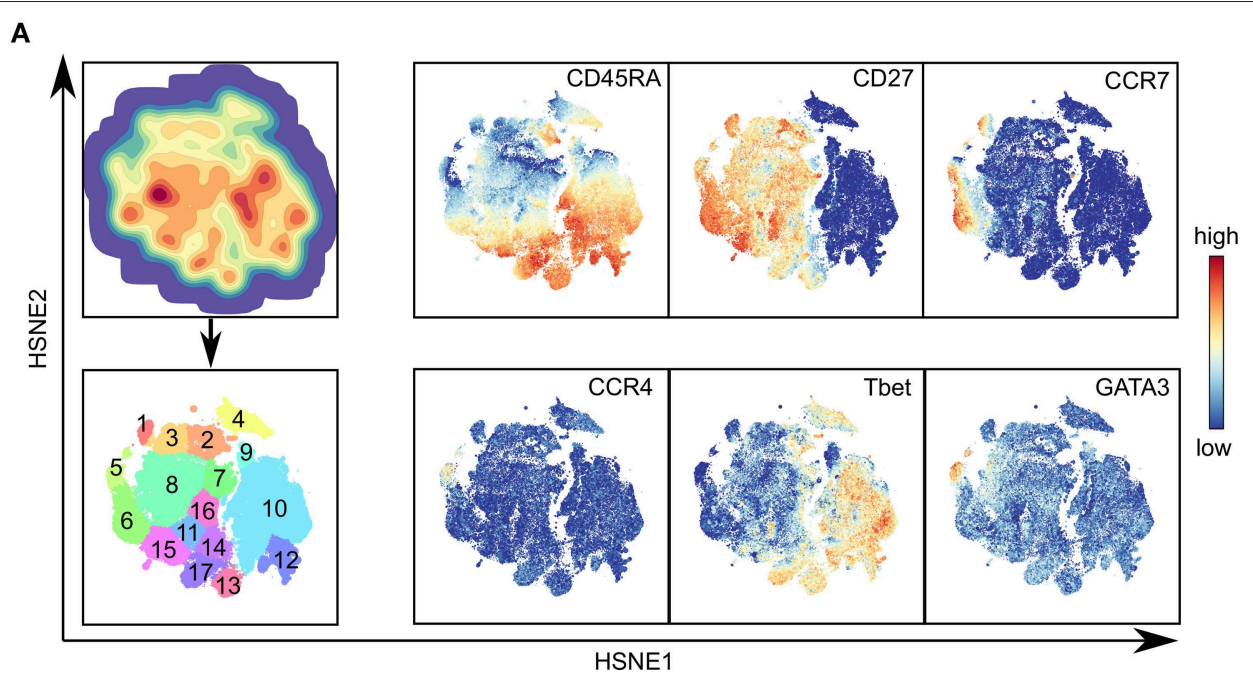

B

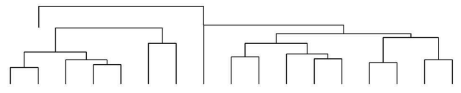

1012171314495162381115167

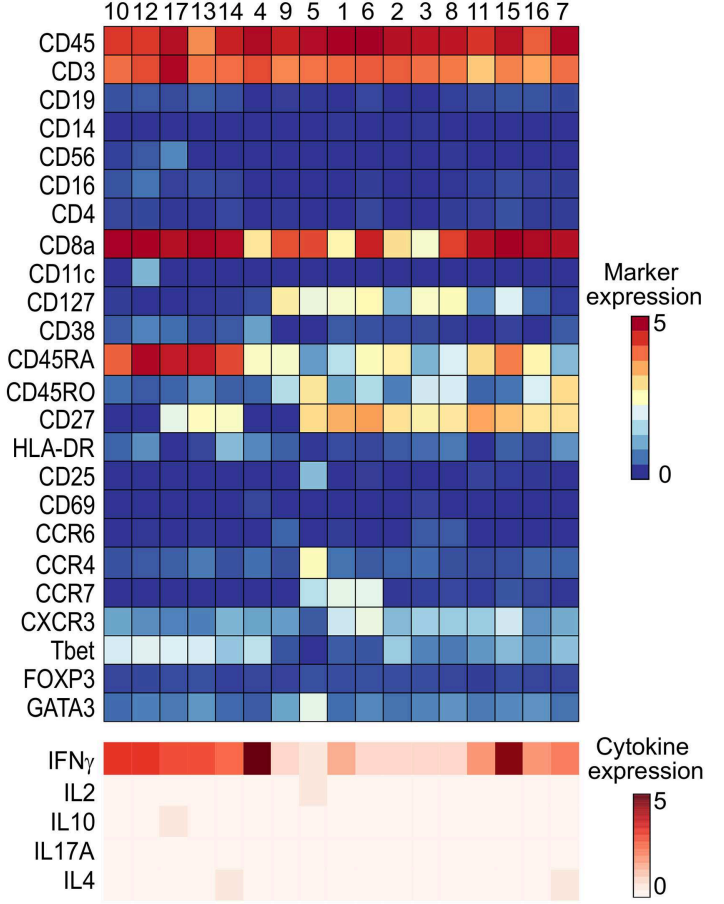

C CXCR3 ${ }^{+}$EMRA (\#10)
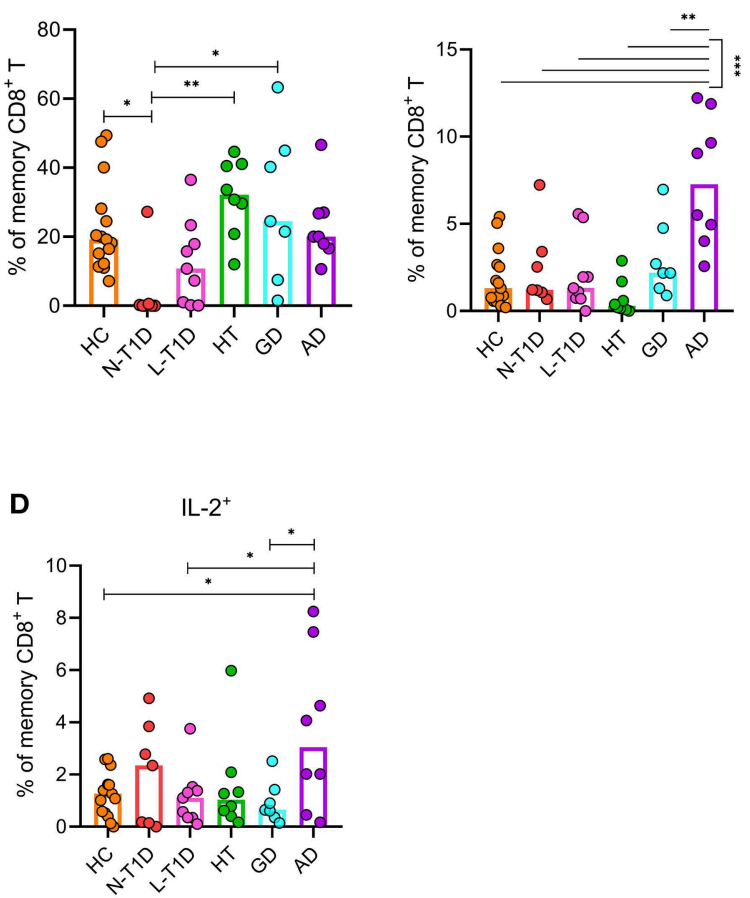

FIGURE 5 | Alterations in distinct memory CD8 ${ }^{+}$T cell subsets with differential cytokine expression in patients with new-onset type 1 diabetes and Addison's disease. (A) HSNE-embedding depicting the local probability density of memory CD8 ${ }^{+} T$ cells (upper first left) and the subsets defined by Gaussian mean-shift clustering (lower first left). Relative ArcSinh5-transformed expression of selected markers in HSNE-embedded memory CD8 ${ }^{+}$T cells. (B) Heatmap showing ArcSinh5-transformed median expression relevant markers (top) and differential median ArcSinh5-expression of cytokines after PMA/ionomycin stimulation (bottom) within the clusters identified in (A). The dendrogram depicts hierarchical clustering of subsets. (C) Frequencies of CXCR3 ${ }^{+}$EMRA (\#10) and CCR4 ${ }^{+}$GATA3 ${ }^{+}$CM (\#5) T cells in healthy controls ( $\mathrm{HC}, n=15)$ and patients with new-onset (N-T1D, $n=7)$ and long-standing (L-T1D, $n=9$ ) type 1 diabetes, Hashimoto's thyroiditis (HT, $n=8)$, Graves' disease (GD, $n=7$ ) and autoimmune Addison's disease (AD, $n=8$ ). (D) Frequency of memory CD8 ${ }^{+}$T cells expressing IL-2 after PMA/ionomycin stimulation. Dots represent individual samples and bars indicate median. One-way ANOVA with Tukey's test for multiple comparisons, ${ }^{\star} p<0.05,{ }^{* \star} p<0.01$, and ${ }^{* \star *} p<0.001$. CM, central memory; EMRA, CD45RA+ effector memory; HSNE, hierarchical stochastic neighbor embedding.

expressing IL-2 was also higher in the AD group than in $\mathrm{HC}(p$ $=0.02)$ and the L-T1D $(p=0.04)$ and GD groups $(p=0.045$, Figure 5D).
Naïve and memory $\mathrm{CD}^{+} \mathrm{T}$ cells comprised 13 and 17 clusters, respectively, whereas 10 cell subsets were identified within the Treg lineage (Supplementary Figures 4A-C). 
Clustering of naïve $\mathrm{CD}^{+} \mathrm{T}$ cells identified 15 subsets (Supplementary Figure 4D). No differences in the frequency of these clusters were observed between the groups.

\section{DISCUSSION}

In this study, we took advantage of high-dimensional mass cytometry to phenotypically characterize PBMC from patients with T1D, HT, GD, and AD. We identified changes in plasmablasts, non-classical Mo and HLA-DR ${ }^{+} \mathrm{NK}$ cells in patients with HT, whereas the N-T1D group had alterations in distinct $\mathrm{NK}$ and effector $\mathrm{CD}^{+} \mathrm{T}$ cell subsets. Moreover, patients with $\mathrm{AD}$ were characterized by an expansion of CCR $4^{+} \mathrm{GATA}^{+}$ central memory $\mathrm{CD} 8^{+} \mathrm{T}$ cells. As it has been hypothesized that these autoimmune endocrine diseases are chiefly driven by Th1and cytotoxic immune responses $(6,10-13)$, it was expected that patients with established autoimmune endocrine diseases would have shared several immunological features. The majority of cell subsets were indeed similar between the patient groups, as well as in comparison with $\mathrm{HC}$, but we were however able to identify distinct alterations in the N-T1D, HT, and AD groups.

A higher frequency of plasmablasts detected in patients with HT suggests that $B$ cells are continuously activated after diagnosis and treatment. B cells might play an important role in HT, as an expansion of peripheral $\mathrm{CD} 27^{+} \mathrm{CD} 138^{+}$plasma cells has been observed in patients with recent-onset of the disease (27). A role for B cells is further supported by a study demonstrating that intra-thyroidal germinal centers were common in patients with HT (28). It has been suggested that plasmablasts modulate effector functions of $\mathrm{CD} 45^{+}$cells via $\mathrm{IgG} / \mathrm{Fc}$-receptor signaling during HT $(8,29,30)$. Peripheral expansion of plasmablasts in an autoimmune context has been attributed to $\mathrm{CD} 11 \mathrm{c}^{+} \mathrm{T}^{- \text {bet }^{+}}$ $B$ cells $(25,26,31)$, which are antigen-experienced $\mathrm{CD} 27^{\mathrm{lo}} \mathrm{IgD}{ }^{\text {lo }}$ $\mathrm{B}$ cells that can differentiate into plasmablasts and produce autoantibodies more efficiently than $\mathrm{CD} 27^{+}$memory B cells (26). We observed that a subset of $\mathrm{CD} 11 \mathrm{c}^{+} \mathrm{CD} 27^{-} \mathrm{CXCR}^{+}{ }^{+}$-bet ${ }^{+}$ $B$ cells was more frequent in patients with HT, supporting the idea that these cells might promote a plasmablast expansion. Alterations within $\mathrm{CD} 19^{+} \mathrm{B}$ cell subsets were only found in patients with HT despite that autoantibodies are also present in T1D, GD and AD. Previous studies addressing peripheral B cells in T1D and GD have reported that frequencies were similar compared to HC (32-34) or that functional responses toward autoantigens were changed $(35,36)$.

Patients with HT were also characterized by an increased frequency of $\mathrm{CD} 86^{+}$non-classical Mo, which has been previously reported in patients with other autoimmune diseases including multiple sclerosis (37), systemic lupus erythematous (38), and primary biliary cirrhosis (39). Variations in sample material, separation protocols, detection methodology and definition of Mo subsets might explain why we did not detect a parallel reduction of classical Mo as observed in other studies $(38,39)$. A higher frequency of non-classical Mo might have a relevant role during HT, as this subset express markers related to antigenpresentation and secrete IL-1 $\beta /$ TNF- $\alpha$ to a higher degree than classical Mo (38). A parallel expansion of plasmablasts and $\mathrm{CD}^{+} 6^{+}$non-classical Mo in the HT group is an interesting observation, as anti-thyroid peroxidase antibodies have been shown to activate $\mathrm{CD} 14^{+}$Mo and thereby induce antibodydependent cell-mediated cytotoxicity and cytokine secretion (8, 29,30 ). Consistent with our results, studies on peripheral and tissue-resident $\mathrm{CD} 14^{+}$Mo from patients with T1D and GD have shown that the frequency of Mo was similar compared to HC $(9,40-42)$. Abovementioned studies revealed nevertheless that the secretion of pro-inflammatory cytokines was enhanced, implying that an altered function of $\mathrm{CD} 14^{+}$Mo is instead the mechanism during T1D and GD.

An expansion of two CD56 ${ }^{\mathrm{dim}}$ NK subsets, expressing HLA$\mathrm{DR}$ at a higher intensity than CD56 $6^{\text {hi }} \mathrm{NK}$ cells, was also detected in samples from patients with HT. This is an interesting finding, as it has been described that CD56 $6^{\text {hi }} \mathrm{NK}$ cells normally express HLA-DR to a higher degree than CD56 ${ }^{\mathrm{dim}}$ NK subsets $(43,44)$. Intriguingly, it has been shown that CD56 ${ }^{\mathrm{dim}} \mathrm{HLA}$ $\mathrm{DR}^{+} \mathrm{NK}$ cells develop during pro-inflammatory conditions (45) and have better stimuli-induced secretion of IFN- $\gamma$ than their HLA-DR ${ }^{-}$counterparts $(44,45)$. Another function attributed to $\mathrm{CD} 56^{\mathrm{dim}} \mathrm{HLA}-\mathrm{DR}^{+} \mathrm{NK}$ cells is their capacity to induce differentiation of naïve $\mathrm{CD} 4^{+} \mathrm{T}$ cells into pre-central memory $\mathrm{T}$ cells (45). In our study, a high expression of IFN- $\gamma$ in both CD56 ${ }^{\text {dim }}{ }^{\text {HLA-DR }}{ }^{+}$subsets might suggest that these cells can be involved in the maintenance of inflammatory immune responses in patients with HT. Several studies have reported an impaired cytotoxicity, yet a normal frequency, of peripheral $\mathrm{CD} 3^{-} \mathrm{CD} 56^{+}$ NK cells in adults with HT, GD, and AD (46-50). An impaired NK cell function has however been attributed to hormonal imbalances and treatment-induced immunosuppression (46-48, $50,51)$.

Most studies addressing NK cells in T1D have focused on their cytotoxic function, whereas studies investigating the phenotype of cell subsets are limited $(52,53)$. It has been recently shown that children with newly diagnosed T1D had reduced frequencies of $\mathrm{CD} 16^{+} \mathrm{CD} 56^{\mathrm{dim}}$ and $\mathrm{CD} 16^{-} \mathrm{CD} 56^{\mathrm{dim}} \mathrm{NK}$ cell subsets than $\mathrm{HC}$ (32). We have previously reported that multiple autoantibody-positive children, who later progressed to T1D, had higher frequencies of two $\mathrm{CD} 8^{+} \mathrm{CD} 16^{+} \mathrm{CD} 56^{\mathrm{dim}} \mathrm{NK}$ cell subsets than autoantibody-negative individuals (18). By using the same mass cytometry panel, we found an expansion of activated mature/effector $\quad \mathrm{CD} 88^{-} \mathrm{CD} 11 \mathrm{c}^{+} \mathrm{CD} 16^{+} \mathrm{CD} 56^{\mathrm{dim}} \mathrm{CD} 69^{+} \mathrm{HLA}-$ $\mathrm{DR}^{-}$NK cells that expressed IFN- $\gamma$ in adults with N-T1D. Expression of CD11c and CD69 on this peripheral cell subset is very intriguing, as these two markers are normally detected to a higher degree in tissue-resident NK cells $(54,55)$. In addition, it has been shown that $\mathrm{CD} 69^{+} \mathrm{NK}$ cells expressed IFN- $\gamma$ to a higher degree than $\mathrm{CD}^{-} 9^{-}$NK cells (56). A higher frequency of activated NK cells with a pro-inflammatory phenotype in adults with newly diagnosed T1D might reflect the ongoing inflammatory process, as this alteration was not observed in samples from patients with L-T1D.

It was interesting that the N-T1D group had a lower frequency of $\mathrm{CXCR}^{+}{ }^{+}$-bet ${ }^{+}$IFN- $\gamma^{+}$TEMRA cells within the $\mathrm{CD}^{+}{ }^{+}$T cell lineage compared with HC. $\mathrm{CD} 8^{+}$TEMRA cells are terminally differentiated cells known to be highly cytotoxic due to their abundant perforin content, cytokine secretion and low activation threshold (57). Studies on pancreatic biopsies from patients with $\mathrm{N}-\mathrm{T} 1 \mathrm{D}$ have shown that $\mathrm{CD} 8^{+} \mathrm{T}$ cells are recruited to insulinpositive islets and are the most prevalent cell type during insulitis 
$(10,20,58)$. Thus, a reduction of TEMRA cells in peripheral blood from newly diagnosed T1D patients might be explained by their migration into the pancreas, where they can contribute to $\beta$-cell apoptosis and dysfunction.

Studies addressing immune responses in patients with $\mathrm{AD}$ are scarce, as this is a rare condition that is often accompanied by other autoimmune endocrine diseases (59). Autoantibodies and chemokines in serum have been extensively studied $(4,60-$ 62), whereas few studies have focused on cellular phenotype and function. It has been shown that $\mathrm{CD}^{+}$and $\mathrm{CD} 4^{+} \mathrm{T}$ cells from patients with AD proliferate and secrete IFN- $\gamma$ upon stimulation with 21-hydroxylase $(6,11,63)$. In this study, we found that $\mathrm{CCR}^{+}{ }^{+} \mathrm{GATA}^{+}{ }^{+}$central memory $\mathrm{CD} 8^{+} \mathrm{T}$ cells were more frequent in patients with $\mathrm{AD}$. This cell subset expressed IL2 at low levels, which could be related to the higher frequency of memory $\mathrm{CD}^{+} \mathrm{T}$ cells expressing IL-2 in patients with $\mathrm{AD}$. Our results further revealed that these "type 2" memory T cells also expressed CD25, but not FOXP3 or the early (CD69) and chronic (HLA-DR) activation markers. A similar central memory $\mathrm{CD} 8^{+} \mathrm{CD} 25^{+} \mathrm{T}$ cell subset has been previously described, which had a Th2-like phenotype, expressed IL-2 and lacked regulatory functions $(64,65)$. Studies addressing corticosteroid treatment and $\mathrm{CD} 8^{+} \mathrm{T}$ cells have reported that the whole $\mathrm{CD} 8^{+} \mathrm{T}$ cell population is suppressed and/or depleted (66-68). As a deeper phenotypic characterization of $\mathrm{CD} 8^{+} \mathrm{T}$ cells was not made in previous studies, it cannot be excluded that an increase of a distinct Th2-like central memory $\mathrm{CD}^{+}{ }^{+} \mathrm{T}$ cell subset in patients with $\mathrm{AD}$ might be the result of corticosteroid treatment. For instance, synthetic glucocorticoids selectively inhibited IFN- $\gamma$ and IRF-1 expression in T cells, without affecting IL-4-signaling (69), leading to a shift toward Th2-biased immune responses (70, 71). Thus, an expansion of peripheral CCR $4^{+} \mathrm{GATA}^{+}$central memory $\mathrm{CD}^{+} \mathrm{T}$ cells in patients with $\mathrm{AD}$ might be due to a drug-induced $\mathrm{CD}^{+} \mathrm{T}$ cell differentiation that does not reflect the pro-inflammatory environment in adrenal glands.

By using a high-dimensional single-cell technology, we were able to simultaneously study lineage, differentiation, activation, and functional markers in major immune cell populations. It could be argued that a limitation of the study is the size of the groups. To avoid methodological variations, intrinsic for this approach, it was important to limit the time window for sample analysis. As only patients diagnosed with one autoimmune endocrine disease were included, it was also difficult to recruit a large number of well-defined patients within a short time period. We were aware of a possible age variation between the groups, especially regarding patients with $\mathrm{AD}$. However, isolated $\mathrm{AD}$ is not highly prevalent in Sweden (Swedish Addison Registry) and younger individuals with $\mathrm{AD}$ tend to develop poly-autoimmunity more frequently than older subjects $(2,5,72)$. Although peripheral blood is not optimal to study immune responses in affected organs, biopsies from the pancreas and adrenal glands are rarely taken for medical and ethical reasons due to the severe complications entailing this procedure. To avoid immunological changes provoked by metabolic disturbances $(51,73)$, only individuals with good hormonal and metabolic control at the time of sampling were included in the study. All patients were medicated according to clinical standards and were treatment-responsive. As the treatments were aimed to normalize derangements in glucose control (T1D), thyroid status (HT and GD), or cortisol levels and electrolytes (AD), medicine doses might have varied between individuals within each disease group. One striking finding was that patients with HT had alterations within different cell lineages not observed in the other groups, especially when compared with the GD patients. Both HT and GD are autoimmune thyroid diseases, but their mechanisms involve different arms of the immune system, leading to distinct destructive effects on the thyroid gland (74). It has been suggested that HT is primarily caused by dysregulation of immune cells, as the disease is clustered with additional autoimmunity, especially against adrenal glands and $\beta$-cells, to a higher degree than GD (75). The immunological alterations in patients with established and treated HT might raise the question whether drugs targeting the immune system could be an attractive complement to conventional hormone replacement.

In conclusion, we show that patients with N-T1D, HT, and $\mathrm{AD}$ had altered frequencies of distinct clusters within antigenpresenting and cytotoxic cell lineages. Importantly, we were able to identify previously unreported alterations in rare cell subsets from patients with $\mathrm{HT}$ and $\mathrm{AD}$. To our knowledge, there are no previous studies addressing differences in PBMC from patients with autoimmune endocrine diseases by a high-dimensional single-cell technology. Our results might contribute to a better understanding of shared and diverging immunological features between autoimmune endocrine diseases. This study was not designed to address the possible functional role of the identified clusters in the pathogenesis of the diseases, which should be addressed in future studies.

\section{MATERIALS AND METHODS Study Design and Participants}

Patients with N-T1D, L-T1D, HT, GD, or AD, as well as HC, were recruited at Uppsala University Hospital between January 2017 and June 2018. All subjects were $18-50$ years old and had no signs of infections, malignancies or other diseases at time of inclusion. Patients had only one known autoimmune endocrine disease and did not present derangements in hormone production and autoantibodies for any of the other studied diseases. HC had no first-degree relatives with autoimmune endocrine diseases, no derangements in hormonal function and were negative for the tested disease-specific autoantibodies. All patients were actively treated for their respective diseases: intensive insulin therapy for T1D, levothyroxine for HT, block-replace therapy (thiamazole with addition of levothyroxine after 4 weeks) for GD and hydrocortisone for AD. Patients with GD had not been previously treated with radioiodine or ablative surgery.

The following parameters were measured at the Clinical Chemistry and Pharmacology Laboratory, Uppsala University Hospital, Sweden: creatinine $(\mu \mathrm{mol} / \mathrm{L})$, fasting glucose $(\mathrm{mmol} / \mathrm{L})$, glycated hemoglobin $(\mathrm{mmol} / \mathrm{mol})$, Cpeptide $(\mathrm{nmol} / \mathrm{L})$, thyroid-stimulating hormone $(\mathrm{mIE} / \mathrm{L})$, free thyroxine $(\mathrm{pmol} / \mathrm{L})$, free triiodothyronine $(\mathrm{pmol} / \mathrm{L})$, serum cortisol (nmol/L), anti-glutamic acid decarboxylase $(\mathrm{IE} / \mathrm{mL})$, anti-tyrosine phosphatase like protein islet antigen-2 
TABLE 1 | Descriptive data of cohort groups.

\begin{tabular}{|c|c|c|c|c|c|c|}
\hline Parameter & $\begin{array}{c}\text { HC } \\
(n=15)\end{array}$ & $\begin{array}{l}\text { N-T1D } \\
(n=7)\end{array}$ & $\begin{array}{l}\text { L-T1D } \\
(n=9)\end{array}$ & $\begin{array}{c}\text { HT } \\
(n=8)\end{array}$ & $\begin{array}{c}\text { GD } \\
(n=7)\end{array}$ & $\begin{array}{c}\text { AD } \\
(n=8)\end{array}$ \\
\hline Age (yr) & $28.9 \pm 1.5$ & $23.3 \pm 1.0$ & $34 \pm 2.9$ & $32 \pm 2.9$ & $34.4 \pm 3.6$ & $36.3 \pm 2.5$ \\
\hline $\operatorname{Sex}(M / F)$ & $7 / 8$ & $5 / 2$ & $5 / 4$ & $2 / 6$ & $2 / 5$ & $6 / 2$ \\
\hline Disease duration (yr) & NA & $0.3 \pm 0.03$ & $19.1 \pm 2.4$ & $4.2 \pm 1.0$ & $0.5 \pm 0.13$ & $6.3 \pm 1.8$ \\
\hline BMI (18.5-25 kg/m²) & $22.9 \pm 0.7$ & $21.1 \pm 0.6$ & $26.2 \pm 1.4$ & $24.3 \pm 1.1$ & $26.7 \pm 1.8$ & $25.4 \pm 1.6$ \\
\hline Creatinine $(60-105 \mu \mathrm{mol} / \mathrm{L})$ & $74.8 \pm 3.4$ & $65.0 \pm 5.2$ & $70.5 \pm 3.2$ & $67.0 \pm 2.0$ & $65.4 \pm 4.7$ & $85.5 \pm 4.1$ \\
\hline F-Glucose (4.0-6.0 mmol/L) & $5.6 \pm 0.1$ & $11.3 \pm 2.0$ & $11.2 \pm 1.0$ & $5.9 \pm 0.2$ & $5.4 \pm 0.3$ & $5.2 \pm 0.2$ \\
\hline HbA1c (27-42 mmol/mol) & $31.7 \pm 0.6$ & $75.4 \pm 11.0$ & $59.2 \pm 3.0$ & $32.5 \pm 1.0$ & $30.9 \pm 1.4$ & $32.9 \pm 0.9$ \\
\hline TSH (0.4-4.0 mlE/L) & $1.9 \pm 0.2$ & $3.8 \pm 1.0$ & $2.3 \pm 0.2$ & $5.9 \pm 2.4$ & $1.0 \pm 0.8$ & $3.0 \pm 0.4$ \\
\hline T3 (3.1-6.8 pmol/L) & $5.1 \pm 0.1$ & $5.4 \pm 0.1$ & $4.8 \pm 0.2$ & $4.5 \pm 0.2$ & $5.8 \pm 1.2$ & $6.3 \pm 0.3$ \\
\hline T4 (12.0-22.0 pmol/L) & $15.6 \pm 0.4$ & $15.2 \pm 0.8$ & $15.0 \pm 0.4$ & $16.0 \pm 0.9$ & $20.4 \pm 2.4$ & $16.3 \pm 1.0$ \\
\hline S-Cortisol (220-650 nmol/L) & $541 \pm 71$ & $497 \pm 136$ & $466 \pm 25$ & $425 \pm 27$ & $341 \pm 27$ & $526 \pm 64$ \\
\hline
\end{tabular}

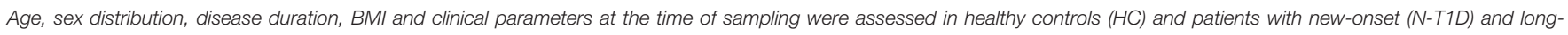

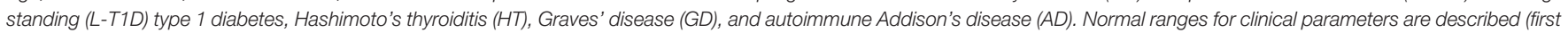

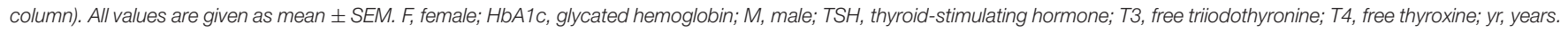

$(\mathrm{kE} / \mathrm{L})$, anti-thyroid peroxidase (kIE/L), thyroid-stimulating immunoglobulins (E/L) and anti-21-hydroxylase (kE/L). Characteristics of the groups are summarized in Table 1. Sex distribution and age were similar between the groups except that the N-T1D group was younger than the AD group $(p<0.05)$.

\section{Blood Sampling and Preparation of PBMC}

Peripheral venous blood was collected in three Vacuette ${ }^{\circledR}$ sodium-heparin tubes à $9 \mathrm{~mL}$ (Greiner Bio-One; Austria) in the morning (8-10 a.m.). All study subjects had been fasting since 10 p.m. the night before sampling. Blood samples were sent to the Pediatric research laboratory, Linköping University, at room-temperature and were processed within $27 \mathrm{~h}$ after sample collection. PBMC were obtained by performing densitygradient centrifugation with Leucosep ${ }^{\circledR}$ tubes (Greiner Bio One; Austria) and Ficoll-Paque ${ }^{\mathrm{TM}}$ PLUS (density $1.077 \pm 0.001 \mathrm{~g} / \mathrm{mL}$, GE Healthcare; UK) according to manufacturer's instructions. Cells were washed in RPMI 1640 w/o L-glutamine (Gibco; US) supplemented with $2 \%(\mathrm{v} / \mathrm{v})$ heat-inactivated FCS (Gibco; US). PBMC were incubated over-night in complete medium (RPMI 1640 w/o L-glutamine supplemented with 10\% (v/v) heat-inactivated FCS) at $2 \times 10^{6}$ cells $/ \mathrm{mL}$.

\section{Mass Cytometry Staining}

The antibody panel, stimulation conditions, and intracellular staining used for mass cytometry in this study were optimized and validated as described elsewhere (18). Monoclonal antibodies and reagents are described in detail in Supplementary Table 1. Purified carrier-free antibodies were conjugated by using Maxpar ${ }^{\circledR}$ antibody labeling kit (Fluidigm; US) according to the manufacturer's instructions.

PBMC $\left(1 \times 10^{7}\right)$ were pre-incubated with anti-CD4- ${ }^{144} \mathrm{Nd}$ for $30 \mathrm{~min}$ at room temperature to improve the anti-CD4 staining upon stimulation. Cells $\left(5 \times 10^{6}\right.$ cells/condition $)$ were left untreated or stimulated with $100 \mathrm{ng} / \mathrm{mL}$ PMA (SigmaAldrich; US) and $1 \mu \mathrm{g} / \mathrm{mL}$ ionomycin (Sigma-Aldrich; US) for $4 \mathrm{~h}$ at $37^{\circ} \mathrm{C}$ in $5 \% \quad \mathrm{CO}_{2}$ in the presence of $2 \mu \mathrm{M}$
Monensin (Affymetrix eBioscience; US) and $3 \mu \mathrm{g} / \mathrm{mL}$ brefeldin A (Affymetrix eBioscience; US). PBMC were washed twice in PBS and stained with $2.5 \mu \mathrm{M}$ Cell-ID ${ }^{\mathrm{TM}}$ Cisplatin (Fluidigm; US) live/dead discriminator for $5 \mathrm{~min}$ at room-temperature. The live/dead-staining was quenched by adding complete medium. Cells were then washed in Maxpar ${ }^{\circledR}$ Cell staining buffer (CSB, Fluidigm; US) and incubated in an extracellular staining cocktail (Supplementary Table 1) for $30 \mathrm{~min}$ at $4^{\circ} \mathrm{C}$. PBMC were washed in CSB and resuspended in FOXP3 Fixation/Permeabilization buffer (Affymetrix eBioscience; US) for $40 \mathrm{~min}$. Cells were then washed with Permeabilization buffer (Affymetrix eBioscience; US) and stained with an intracellular staining cocktail for $30 \mathrm{~min}$ at $4^{\circ} \mathrm{C}$. Samples were washed twice in Permeabilization buffer, once in CSB and then fixed over-night in PBS with $2 \%$ paraformaldehyde (Novakemi AB; Sweden) at $4^{\circ} \mathrm{C}$.

\section{Sample Barcoding and Data Acquisition}

Barcoded sample batches were processed simultaneously to reduce data collection variability. Sample barcoding and data acquisition were carried out as previously described (18). Briefly, cells were washed twice in Maxpar ${ }^{\circledR}$ Barcode perm buffer (Fluidigm; US) and each sample was stained with a different barcode combination using Cell-ID 20-plex Pd-barcoding kit (Fluidigm; US) for $30 \mathrm{~min}$ at room temperature. After washing twice in CSB, samples were pooled together into one tube. Cells were incubated for $20 \mathrm{~min}$ at room temperature with $125 \mathrm{nM}$ Cell-ID ${ }^{\mathrm{TM}}$ DNA Intercalator-Ir191/193 (Fluidigm; US), washed twice with CSB and once with Di water and lastly resuspended with $0.1 \%$ EQ four element calibration beads (Fluidigm; US). Data were acquired with a CyTOF ${ }^{\circledR}{ }^{\circledR}$ instrument (Fluidigm; US). After acquisition, data were concatenated, normalized using mass bead signal and de-barcoded using the CyTOF 2 software.

\section{Data Analysis and Statistics}

Data of single, live $\mathrm{CD} 45^{+}$cells from each sample were manually gated using Cytobank (76) (Supplementary Figure 1A). Data were first hyperbolic ArcSinh-transformed with a cofactor 
of 5 and then a 5-level HSNE analysis was performed in Cytosplore $^{+\mathrm{HSNE}}$ (77) with 30 perplexity and 1,000 iterations (default settings). All markers were selected in HSNE analysis except cytokines (IFN- $\gamma$, IL-2, IL-4, IL-10, and IL-17A). Major cell lineages were identified at the overview level and analyzed separately in a data-driven manner (77). To facilitate subset identification and reduce computing time, $\mathrm{CD} 4^{+}$and $\mathrm{CD} 8^{+}$ $\mathrm{T}$ cells were further divided into naïve and memory cells in subsequent levels according to the expression of CD45RA, CD45RO, CCR7, and CD27. Clustering was performed by GMS in Cytosplore. Clusters showing similar phenotype were manually merged. Further exploration of cluster frequencies and median ArcSinh5-transformed marker expression was performed using Cytofast (78). For cytokine expression, differential median ArcSinh5-expression between clusters with similar phenotype in unstimulated and stimulated samples was calculated. Shapio Wilk's normality test was used to evaluate data distribution. Chi-square test was used to assess differences in sex distribution between the study groups. One-way ANOVA and Tukey's test for multiple comparisons were applied for statistical analysis of data $(\alpha=0.05)$. All statistical analyses were performed in GraphPad Prism 8 software.

\section{Study Approval}

This study was approved by the Regional Research Ethical Committee in Uppsala (Dnr 2014/485) and was consistent with The Declaration of Helsinki. All participants gave their written informed consent prior to inclusion in the study.

\section{DATA AVAILABILITY STATEMENT}

The datasets generated for this study are available on request to the corresponding author.

\section{ETHICS STATEMENT}

The studies involving human participants were reviewed and approved by Regional Research Ethical Committee in Uppsala. The patients/participants provided their written informed consent to participate in this study.

\section{REFERENCES}

1. Shoenfeld Y, Isenberg DA. The mosaic of autoimmunity. Immunol Today. (1989) 10:123-6. doi: 10.1016/0167-5699(89)90245-4

2. Anaya JM. Common mechanisms of autoimmune diseases (the autoimmune tautology). Autoimmun Rev. (2012) 11:7814. doi: 10.1016/j.autrev.2012.02.002

3. Chantzichristos D, Persson A, Eliasson B, Miftaraj M, Franzen S, Svensson $\mathrm{AM}$, et al. Incidence, prevalence and seasonal onset variation of Addison's disease among persons with type 1 diabetes mellitus: nationwide, matched cohort studies. Eur J Endocrinol. (2018) 178:113-20. doi: 10.1530/EJE-17-0751

4. Erichsen MM, Lovas K, Skinningsrud B, Wolff AB, Undlien DE, Svartberg J, et al. Clinical, immunological, and genetic features of autoimmune primary adrenal insufficiency: observations from a Norwegian registry. J Clin Endocrinol Metab. (2009) 94:4882-90. doi: 10.1210/jc.200 9-1368

\section{AUTHOR CONTRIBUTIONS}

P-OC and DE were responsible for study conception and handling of clinical data. DE, P-OC, and SB recruited study subjects. LM, HB, and RC designed the immunological experiments. HB, RC, and MP designed the panel and protocol for mass cytometry. LM, HB, and MP performed mass cytometry experiments. Acquisition and analysis of data were performed by MP and HB, respectively. Data were interpreted by LM, HB, and RC. LM, RC, and HB wrote the manuscript. The manuscript was revised by DE and P-OC. Final approval for submission was given by all authors.

\section{FUNDING}

This study was supported by The Swedish Research Council grants 2017-01343 and 2014-07054; The Erling-Persson Family Foundation; The Swedish Diabetes Foundation; The Swedish Child Diabetes Foundation; Diabetes Wellness Sverige; and The Novo Nordisk Foundation. Funders were neither involved in the study design, acquisition, analysis and interpretation of data nor writing and submission of this article.

\section{ACKNOWLEDGMENTS}

We would like to thank Karin Kjellström and Rebecka Hilmius, nurses at the Unit of Endocrinology and Diabetes, Uppsala University Hospital, for handling the patient samples. We acknowledge the assistance from medical doctors at Uppsala University Hospital and primary healthcare for patient recruitment. We also acknowledge the Flow cytometry unit at Core Facility, Linköping University for operating the CyTOF $2^{\circledR}$ instrument. Finally, we thank all patients and healthy controls who participated in this study.

\section{SUPPLEMENTARY MATERIAL}

The Supplementary Material for this article can be found online at: https://www.frontiersin.org/articles/10.3389/fimmu. 2020.00288/full\#supplementary-material

5. Dalin F, Nordling Eriksson G, Dahlqvist P, Hallgren A, Wahlberg J, et al. Clinical and immunological characteristics of autoimmune addison disease: a nationwide Swedish multicenter study. J Clin Endocrinol Metab. (2017) 102:379-89. doi: 10.1210/jc.2016-2522

6. Bratland E, Skinningsrud B, Undlien DE, Mozes E, Husebye ES. T cell responses to steroid cytochrome $\mathrm{P} 450$ 21-hydroxylase in patients with autoimmune primary adrenal insufficiency. J Clin Endocrinol Metab. (2009) 94:5117-24. doi: 10.1210/jc.2009-1115

7. Reijonen H, Daniels TL, Lernmark A, Nepom GT. GAD65specific autoantibodies enhance the presentation of an immunodominant T-cell epitope from GAD65. Diabetes. (2000) 49:1621-6. doi: 10.2337/diabetes.49.10.1621

8. Bogner U, Schleusener $\mathrm{H}$, Wall JR. Antibody-dependent cell mediated cytotoxicity against human thyroid cells in Hashimoto's thyroiditis but not Graves' disease. J Clin Endocrinol Metab. (1984) 59:734-8. doi: 10.1210/jcem-59-4-734 
9. Bradshaw EM, Raddassi K, Elyaman W, Orban T, Gottlieb PA, Kent SC, et al. Monocytes from patients with type 1 diabetes spontaneously secrete proinflammatory cytokines inducing Th17 cells. J Immunol. (2009) 183:44329. doi: 10.4049/jimmunol.0900576

10. Willcox A, Richardson SJ, Bone AJ, Foulis AK, Morgan NG. Analysis of islet inflammation in human type 1 diabetes. Clin Exp Immunol. (2009) 155:173-81. doi: 10.1111/j.1365-2249.2008.03860.x

11. Rottembourg D, Deal C, Lambert M, Mallone R, Carel JC, Lacroix A, et al. 21Hydroxylase epitopes are targeted by CD8 T cells in autoimmune Addison's disease. J Autoimmun. (2010) 35:309-15. doi: 10.1016/j.jaut.2010.07.001

12. Knight RR, Kronenberg D, Zhao M, Huang GC, Eichmann M, Bulek A, et al. Human beta-cell killing by autoreactive preproinsulin-specific CD8 T cells is predominantly granule-mediated with the potency dependent upon T-cell receptor avidity. Diabetes. (2013) 62:205-13. doi: 10.2337/db12-0315

13. Nanba $T$, Watanabe $M$, Inoue $N$, Iwatani $Y$. Increases of the Th1/Th2 cell ratio in severe Hashimoto's disease and in the proportion of Th17 cells in intractable Graves' disease. Thyroid. (2009) 19:495-501. doi: 10.1089/thy.2008.0423

14. Phenekos C, Vryonidou A, Gritzapis AD, Baxevanis CN, Goula M, Papamichail M. Th1 and Th2 serum cytokine profiles characterize patients with Hashimoto's thyroiditis (Th1) and Graves' disease (Th2). Neuroimmunomodulation. (2004) 11:209-13. doi: 10.1159/0000 78438

15. Arif S, Moore F, Marks K, Bouckenooghe T, Dayan CM, Planas R, et al. Peripheral and islet interleukin-17 pathway activation characterizes human autoimmune diabetes and promotes cytokine-mediated beta-cell death. Diabetes. (2011) 60:2112-9. doi: 10.2337/db10-1643

16. Glick AB, Wodzinski A, Fu P, Levine AD, Wald DN. Impairment of regulatory T-cell function in autoimmune thyroid disease. Thyroid. (2013) 23:8718. doi: 10.1089/thy.2012.0514

17. Lindley S, Dayan CM, Bishop A, Roep BO, Peakman M, Tree TI. Defective suppressor function in $\mathrm{CD} 4(+) \mathrm{CD} 25(+)$ T-cells from patients with type 1 diabetes. Diabetes. (2005) 54:92-9. doi: 10.2337/diabetes.54.1.92

18. Barcenilla H, Akerman L, Pihl M, Ludvigsson J, Casas R. Mass cytometry identifies distinct subsets of regulatory $\mathrm{T}$ cells and natural killer cells associated with high risk for type 1 diabetes. Front Immunol. (2019) 10:982. doi: 10.3389/fimmu.2019.00982

19. Wang YJ, Traum D, Schug J, Gao L, Liu C, Atkinson MA, et al. Multiplexed in situ imaging mass cytometry analysis of the human endocrine pancreas and immune system in type 1 diabetes. Cell Metab. (2019) 29:76983.e4. doi: 10.1016/j.cmet.2019.01.003

20. Damond N, Engler S, Zanotelli VRT, Schapiro D, Wasserfall CH, Kusmartseva I, et al. A map of human type 1 diabetes progression by imaging mass cytometry. Cell Metab. (2019) 29:755-68.e5. doi: 10.1016/j.cmet.2018.11.014

21. O'Gorman WE, Kong DS, Balboni IM, Rudra P, Bolen CR, Ghosh D, et al. Mass cytometry identifies a distinct monocyte cytokine signature shared by clinically heterogeneous pediatric SLE patients. J Autoimmun. (2017) 81, 74-89. doi: 10.1016/j.jaut.2017.03.010

22. Rao DA, Gurish MF, Marshall JL, Slowikowski K, Fonseka CY, Liu Y, et al. Pathologically expanded peripheral $\mathrm{T}$ helper cell subset drives B cells in rheumatoid arthritis. Nature. (2017) 542:110-4. doi: 10.1038/nature20810

23. van Unen V, Li N, Molendijk I, Temurhan M, Hollt T, van der Meulende Jong AE, et al. Mass cytometry of the human mucosal immune system identifies tissue- and disease-associated immune subsets. Immunity. (2016) 44:1227-39. doi: 10.1016/j.immuni.2016.04.014

24. van der Kroef M, van den Hoogen LL, Mertens JS, Blokland SLM, Haskett S, Devaprasad A, et al. Cytometry by time of flight identifies distinct signatures in patients with systemic sclerosis, systemic lupus erythematosus and Sjögrens syndrome. Eur J Immunol. (2020) 50:119-29. doi: 10.1002/eji.201948129

25. Rubtsov AV, Rubtsova K, Fischer A, Meehan RT, Gillis JZ, Kappler JW, et al. Toll-like receptor 7 (TLR7)-driven accumulation of a novel CD11c(+) B-cell population is important for the development of autoimmunity. Blood. (2011) 118:1305-15. doi: 10.1182/blood-2011-01-331462

26. Wang S, Wang J, Kumar V, Karnell JL, Naiman B, Gross PS, et al. IL-21 drives expansion and plasma cell differentiation of autoreactive CD11c(hi)Tbet(+) B cells in SLE. Nat Commun. (2018) 9:1758. doi: 10.1038/s41467-018-0 3750-7

27. Liu Y, You R, Yu N, Gong Y, Qu C, Zhang Y, et al. Increased proportions of $\mathrm{Tc} 17$ cells and NK cells may be risk factors for disease progression in Hashimoto's thyroiditis. Int Immunopharmacol. (2016) 40:3328. doi: 10.1016/j.intimp.2016.09.016

28. Armengol MP, Juan M, Lucas-Martin A, Fernandez-Figueras MT, Jaraquemada D, Gallart T, et al. Thyroid autoimmune disease: demonstration of thyroid antigen-specific $\mathrm{B}$ cells and recombination-activating gene expression in chemokine-containing active intrathyroidal germinal centers. Am J Pathol. (2001) 159:861-73. doi: 10.1016/S0002-9440(10)61762-2

29. Rebuffat SA, Nguyen B, Robert B, Castex F, Peraldi-Roux S. Antithyroperoxidase antibody-dependent cytotoxicity in autoimmune thyroid disease. J Clin Endocrinol Metab. (2008) 93:929-34. doi: 10.1210/jc.2007-2042

30. Nielsen $\mathrm{CH}$, Brix $\mathrm{TH}$, Leslie RG, Hegedus L. A role for autoantibodies in enhancement of pro-inflammatory cytokine responses to a self-antigen, thyroid peroxidase. Clin Immunol. (2009) 133:218-27. doi: 10.1016/j.clim.2009.07.014

31. Rubtsova K, Rubtsov AV, Thurman JM, Mennona JM, Kappler JW, Marrack P. B cells expressing the transcription factor T-bet drive lupus-like autoimmunity. J Clin Investig. (2017) 127:1392-404. doi: 10.1172/JCI91250

32. Oras A, Peet A, Giese T, Tillmann V, Uibo R. A study of 51 subtypes of peripheral blood immune cells in newly diagnosed young type 1 diabetes patients. Clin Exp Immunol. (2019) 198:57-70. doi: 10.1111/cei.13332

33. Hanley P, Sutter JA, Goodman NG, Du Y, Sekiguchi DR, Meng W, et al. Circulating $B$ cells in type 1 diabetics exhibit fewer maturation-associated phenotypes. Clin Immunol. (2017) 183:336-43. doi: 10.1016/j.clim.2017.09.021

34. Powell WE, Hanna SJ, Hocter CN, Robinson E, Davies J, Dunseath GJ, et al. Loss of CXCR3 expression on memory B cells in individuals with long-standing type 1 diabetes. Diabetologia. (2018) 61:1794-803. doi: 10.1007/s00125-018-4651-x

35. Kristensen B, Hegedus L, Lundy SK, Brimnes MK, Smith TJ, Nielsen CH. Characterization of regulatory B cells in Graves' Disease and Hashimoto's Thyroiditis. PLoS ONE. (2015) 10:e0127949. doi: 10.1371/journal.pone.0127949

36. Nielsen CH, Moeller AC, Hegedus L, Bendtzen K, Leslie RG. Self-reactive $\mathrm{CD} 4+\mathrm{T}$ cells and B cells in the blood in health and autoimmune disease: increased frequency of thyroglobulin-reactive cells in Graves' disease. J Clin Immunol. (2006) 26:126-37. doi: 10.1007/s10875-006-9000-z

37. Gjelstrup MC, Stilund M, Petersen T, Moller HJ, Petersen EL, Christensen T. Subsets of activated monocytes and markers of inflammation in incipient and progressed multiple sclerosis. Immunol Cell Biol. (2018) 96:16074. doi: $10.1111 /$ imcb. 1025

38. Mukherjee R, Kanti Barman P, Kumar Thatoi P, Tripathy R, Kumar Das B, Ravindran B. Non-Classical monocytes display inflammatory features: validation in sepsis and systemic lupus erythematous. Sci Rep. (2015) 5:13886. doi: $10.1038 /$ srep 13886

39. Peng A, Ke P, Zhao R, Lu X, Zhang C, Huang X, et al. Elevated circulating CD14(low)CD16(+) monocyte subset in primary biliary cirrhosis correlates with liver injury and promotes Th1 polarization. Clin Exp Med. (2016) 16:511-21. doi: 10.1007/s10238-015-0381-2

40. Meyers AJ, Shah RR, Gottlieb PA, Zipris D. Altered Toll-like receptor signaling pathways in human type 1 diabetes. J Mol Med. (2010) 88:122131. doi: 10.1007/s00109-010-0666-6

41. Sun L, Zhang X, Dai F, Shen J, Ren C, Zuo C, et al. Elevated interleukin1beta in peripheral blood mononuclear cells contributes to the pathogenesis of autoimmune thyroid diseases, especially of Hashimoto thyroiditis. Endocr Res. (2016) 41:185-92. doi: 10.3109/07435800.2015.1124439

42. Kawabe Y, Eguchi K, Shimomura C, Mine M, Otsubo T, Ueki Y, et al. Interleukin-1 production and action in thyroid tissue. J Clin Endocrinol Metab. (1989) 68:1174-83. doi: 10.1210/jcem-68-6-1174

43. Poli A, Michel T, Theresine M, Andres E, Hentges F, Zimmer J. CD56bright natural killer (NK) cells: an important NK cell subset. Immunology. (2009) 126:458-65. doi: 10.1111/j.1365-2567.2008.03027.x

44. Erokhina SA, Streltsova MA, Kanevskiy LM, Telford WG, Sapozhnikov AM, Kovalenko EI. HLA-DR(+) NK cells are mostly characterized by less mature phenotype and high functional activity. Immunol Cell Biol. (2018) 96:21228. doi: 10.1111/imcb.1032

45. Loyon R, Picard E, Mauvais O, Queiroz L, Mougey V, Pallandre JR, et al. IL-21-Induced MHC Class II+ NK cells promote the expansion 
of human uncommitted CD4+ central memory $\mathrm{T}$ cells in a macrophage migration inhibitory factor-dependent manner. J Immunol. (2016) 197:8596. doi: 10.4049/jimmunol.1501147

46. Bancos I, Hazeldine J, Chortis V, Hampson P, Taylor AE, Lord JM, et al. Primary adrenal insufficiency is associated with impaired natural killer cell function: a potential link to increased mortality. Eur J Endocrinol. (2017) 176:471-80. doi: 10.1530/EJE-16-0969

47. Papic M, Stein-Streilein J, Zakarija M, McKenzie JM, Guffee J, Fletcher MA. Suppression of peripheral blood natural killer cell activity by excess thyroid hormone. J Clin Investig. (1987) 79:404-8. doi: 10.1172/JCI112826

48. Marazuela M, Vargas JA, Alvarez-Mon M, Albarran F, Lucas T, Durantez A. Impaired natural killer cytotoxicity in peripheral blood mononuclear cells in Graves' disease. Eur J Endocrinol. (1995) 132:175-80. doi: 10.1530/eje.0.1320175

49. Amino N, Mori H, Iwatani Y, Asari S, Izumiguchi Y, Miyai K. Peripheral $\mathrm{K}$ lymphocytes in autoimmune thyroid disease: decrease in Graves' disease and increase in Hashimoto's disease. J Clin Endocrinol Metab. (1982) 54:58791. doi: $10.1210 /$ jcem-54-3-587

50. Wenzel BE, Chow A, Baur R, Schleusener H, Wall JR. Natural killer cell activity in patients with Graves' disease and Hashimoto's thyroiditis. Thyroid. (1998) 8:1019-22. doi: 10.1089/thy.1998.8.1019

51. Lee EK, Sunwoo JB. Natural killer cells and thyroid diseases. Endocrinol Metab. (2019) 34:132-7. doi: 10.3803/EnM.2019.34.2.132

52. Fraker C, Bayer AL. The expanding role of natural killer cells in type 1 diabetes and immunotherapy. Curr Diab Rep. (2016) 16:109. doi: 10.1007/s11892-016-0806-7

53. Marca V, Gianchecchi E, Fierabracci A. Type 1 diabetes and its multifactorial pathogenesis: the putative role of NK cells. Int J Mol Sci. (2018) 19:794. doi: 10.3390/ijms19030794

54. Tang L, Peng H, Zhou J, Chen Y, Wei H, Sun R, et al. Differential phenotypic and functional properties of liver-resident NK cells and mucosal ILC1s. J Autoimmun. (2016) 67:29-35. doi: 10.1016/j.jaut.2015. 09.004

55. van der Molen RG, Schutten JH, van Cranenbroek B, ter Meer M, Donckers J, Scholten RR, et al. Menstrual blood closely resembles the uterine immune micro-environment and is clearly distinct from peripheral blood. Hum Reprod. (2014) 29:303-14. doi: 10.1093/humrep/det398

56. Kang SJ, Jin HM, Cho YN, Kim SE, Kim UJ, Park KH, et al. Increased level and interferon-gamma production of circulating natural killer cells in patients with scrub typhus. PLoS Negl Trop Dis. (2017) 11:e0005815. doi: 10.1371/journal.pntd.0005815

57. Sallusto F, Geginat J, Lanzavecchia A. Central memory and effector memory T cell subsets: function, generation, and maintenance. Ann Rev Immunol. (2004) 22:745-63. doi: 10.1146/annurev.immunol.22.012703.1 04702

58. Leete P, Willcox A, Krogvold L, Dahl-Jorgensen K, Foulis AK, Richardson SJ, et al. Differential insulitic profiles determine the extent of beta-cell destruction and the age at onset of type 1 diabetes. Diabetes. (2016) 65:13629. doi: $10.2337 / \mathrm{db} 15-1615$

59. Napier C, Pearce SH. Autoimmune Addison's disease. Presse Med. (2012) 41:e626-35. doi: 10.1016/j.lpm.2012.09.010

60. Winqvist O, Karlsson FA, Kampe O. 21-Hydroxylase, a major autoantigen in idiopathic Addison's disease. Lancet. (1992) 339:1559-62. doi: 10.1016/0140-6736(92)91829-W

61. Boe AS, Bredholt G, Knappskog PM, Hjelmervik TO, Mellgren G, Winqvist O, et al. Autoantibodies against 21-hydroxylase and side-chain cleavage enzyme in autoimmune Addison's disease are mainly immunoglobulin G1. Eur J Endocrinol. (2004) 150:49-56. doi: 10.1530/eje.0.1500049

62. Rotondi M, Falorni A, De Bellis A, Laureti S, Ferruzzi P, Romagnani $\mathrm{P}$, et al. Elevated serum interferon-gamma-inducible chemokine-10/CXC chemokine ligand-10 in autoimmune primary adrenal insufficiency and in vitro expression in human adrenal cells primary cultures after stimulation with proinflammatory cytokines. J Clin Endocrinol Metab. (2005) 90:235763. doi: 10.1210/jc.2004-1062

63. Dawoodji A, Chen JL, Shepherd D, Dalin F, Tarlton A, Alimohammadi $\mathrm{M}$, et al. High frequency of cytolytic 21-hydroxylase-specific CD8+ T cells in autoimmune Addison's disease patients. J Immunol. (2014) 193:211826. doi: 10.4049/jimmunol.1400056
64. Herndler-Brandstetter D, Schwaiger S, Veel E, Fehrer C, Cioca DP, Almanzar G, et al. CD25-expressing CD8+ T cells are potent memory cells in old age. $J$ Immunol.. (2005) 175:1566-74. doi: 10.4049/jimmunol.175.3.1566

65. Schwaiger S, Wolf AM, Robatscher P, Jenewein B, Grubeck-Loebenstein B. IL-4-producing $\mathrm{CD} 8+\mathrm{T}$ cells with a $\mathrm{CD} 62 \mathrm{~L}++$ (bright) phenotype accumulate in a subgroup of older adults and are associated with the maintenance of intact humoral immunity in old age. J Immunol. (2003) 170:613-9. doi: 10.4049/jimmunol.170.1.613

66. Zuska-Prot M, Maslanka T. Inhaled glucocorticoid treatment prevents the response of CD8(+) T cells in a mouse model of allergic asthma and causes their depletion outside the respiratory system. Int Immunopharmacol. (2017) 53:63-72. doi: 10.1016/j.intimp.2017.10.012

67. Theiss-Suennemann J, Jorss K, Messmann JJ, Reichardt SD, Montes-Cobos E, Luhder F, et al. Glucocorticoids attenuate acute graft-versus-host disease by suppressing the cytotoxic capacity of CD8(+) T cells. J Pathol. (2015) 235:646-55. doi: 10.1002/path.4475

68. Baris HE, Baris S, Karakoc-Aydiner E, Gokce I, Yildiz N, Cicekkoku D, et al. The effect of systemic corticosteroids on the innate and adaptive immune system in children with steroid responsive nephrotic syndrome. Eur J Pediatr. (2016) 175:685-93. doi: 10.1007/s00431-016-2694-x

69. Franchimont D, Galon J, Gadina M, Visconti R, Zhou Y, Aringer M, et al. Inhibition of Th1 immune response by glucocorticoids: dexamethasone selectively inhibits IL-12-induced Stat4 phosphorylation in T lymphocytes. $J$ Immunol.. (2000) 164:1768-74. doi: 10.4049/jimmunol.164.4.1768

70. Ramirez F, Fowell DJ, Puklavec M, Simmonds S, Mason D. Glucocorticoids promote a $\mathrm{TH} 2$ cytokine response by $\mathrm{CD} 4+\mathrm{T}$ cells in vitro. J Immunol. (1996) 156:2406-12.

71. Akdis CA, Blesken T, Akdis M, Alkan SS, Heusser CH, Blaser K. Glucocorticoids inhibit human antigen-specific and enhance total IgE and IgG4 production due to differential effects on $\mathrm{T}$ and B cells in vitro. Eur $\mathrm{J}$ Immunol. (1997) 27:2351-7. doi: 10.1002/eji.1830270933

72. Coco G, Dal Pra C, Presotto F, Albergoni MP, Canova C, Pedini B, et al. Estimated risk for developing autoimmune Addison's disease in patients with adrenal cortex autoantibodies. J Clin Endocrinol Metab. (2006) 91:163745. doi: 10.1210/jc.2005-0860

73. Ratter JM, Rooijackers HMM, Jacobs CWM, de Galan BE, Tack CJ, Stienstra R. Hypoglycaemia induces recruitment of non-classical monocytes and cytotoxic lymphocyte subsets in type 1 diabetes. Diabetologia. (2018) 61:206971. doi: 10.1007/s00125-018-4683-2

74. Stassi G, De Maria R. Autoimmune thyroid disease: new models of cell death in autoimmunity. Nat Rev Immunol. (2002) 2:195-204. doi: 10.1038/nri750

75. Wiebolt J, Achterbergh R, den Boer A, van der Leij S, Marsch E, Suelmann $B$, et al. Clustering of additional autoimmunity behaves differently in Hashimoto's patients compared with Graves' patients. Eur J Endocrinol. (2011) 164:789-94. doi: 10.1530/EJE-10-1172

76. Kotecha N, Krutzik PO, Irish JM. Web-based analysis and publication of flow cytometry experiments. Curr Protoc Cytom. (2010) 53:10.17.1-10.17.24. doi: 10.1002/0471142956.cy1017s53

77. van Unen V, Hollt T, Pezzotti N, Li N, Reinders MJT, Eisemann E, et al. Visual analysis of mass cytometry data by hierarchical stochastic neighbour embedding reveals rare cell types. Nat Commun. (2017) 8:1740. doi: 10.1038/s41467-017-01689-9

78. Beyrend G, Stam K, Hollt T, Ossendorp F, Arens R. Cytofast: a workflow for visual and quantitative analysis of flow and mass cytometry data to discover immune signatures and correlations. Comput Struct Biotechnol J. (2018) 16:435-42. doi: 10.1016/j.csbj.2018.10.004

Conflict of Interest: The authors declare that the research was conducted in the absence of any commercial or financial relationships that could be construed as a potential conflict of interest.

Copyright $\odot 2020$ Magnusson, Barcenilla, Pihl, Bensing, Espes, Carlsson and Casas. This is an open-access article distributed under the terms of the Creative Commons Attribution License (CC BY). The use, distribution or reproduction in other forums is permitted, provided the original author(s) and the copyright owner(s) are credited and that the original publication in this journal is cited, in accordance with accepted academic practice. No use, distribution or reproduction is permitted which does not comply with these terms. 